\title{
RAZPRAVE
}

\section{TRENDI PRETOKOV REK V SLOVENSKIH ALPAH MED LETOMA 1961 IN 2010}

\author{
AVTORJA \\ dr. Mauro Hrvatin \\ Znanstvenoraziskovalni center Slovenske akademije znanosti in umetnosti, Geografski inštitut Antona Melika, \\ Gosposka ulica 13, SI - 1000 Ljubljana, Slovenija \\ mauro@zrc-sazu.si
}

\section{dr. Matija Zorn}

Znanstvenoraziskovalni center Slovenske akademije znanosti in umetnosti, Geografski inštitut Antona Melika, Gosposka ulica 13, SI - 1000 Ljubljana, Slovenija

matija.zorn@zrc-sazu.si

DOI: $10.3986 / G V 89201$

UDK: 551.583:556.535(497.4)"1961/2010"

COBISS: 1.01

\section{IZVLEČEK}

\section{Trendi pretokov rek $v$ slovenskih Alpah med letoma 1961 in 2010}

$V$ prispevku obravnavamo trende letnih pretokov rek, ki imajo povirja v slovenskem visokogorju. Obravnavane so reke: Soča, Koritnica, Tolminka, Mostnica, Sava Bohinjka, Sava Dolinka, Radovna, Tržiška Bistrica, Kokra, Kamniška Bistrica, Savinja in Meža. Pretoki so v največji meri posledica podnebnega dogajanja, zato spremembe trendov pretokov povezujemo s podnebnimi spremembami. Te se kažejo v manjši letni količini padavin ter rasti povprečne letne temperature. Ne smemo pa pri spremenljivosti vodnih razmer pozabiti na človeka, ki lahko s spremembami rabe tal močno vpliva na površinski odtok padavin. Rezultati kažejo, da povprečni srednji letni pretoki na vseh obravnavanih rekah podajo, pri večini rek pa padajo tudi absolutni minimalni in absolutni maksimalni pretoki. Poleg tega beležimo spremembe v pretočnih režimih, pri katerih postajata spomladanski (glavni) in jesenski (drugotni) pretočni višek vse bolj izenačena, zimski (glavni) in poletni (drugotni) pretočni nižek pa vse bolj izrazita.

\section{KLJUČNE BESEDE}

geografija voda, podnebna geografija, trendi pretokov, pretočni režimi, podnebne spremembe, spremembe rabe tal, Alpe

\section{ABSTRACT}

\section{River discharge trends in Slovenian Alps between 1961 and 2010}

This article discusses the annual discharge of rivers that have their catchment areas in the Slovenian high mountains. They include the Soča, Koritnica, Tolminka, Mostnica, Sava Bohinjka, Sava Dolinka, Radovna, Tržiška Bistrica, Kokra, Kamniška Bistrica, Savinja, and Meža rivers. Their discharges are largely the result of climate developments, which is why changes in discharge trends are associated with climate change. This change is shown in lower annual precipitation and the increase in annual temperature. However, with regard to the variability of water conditions, human-induced land-use changes should not be ignored because they can have a strong impact on the surface runoff of precipitation. The findings show that average mean annual discharges are falling on all rivers, and that absolute minimum and maximum discharges 
are also falling on the majority of rivers. In addition, changes have also been recorded in discharge regimes: the spring (primary) and fall (secondary) discharge maximums are becoming increasingly similar, and the winter (primary) and summer (secondary) discharge minimums are becoming increasingly distinct.

\section{KEY WORDS}

hydrogeography, climate geography, discharge trends, discharge regimes, climate changes, land use changes, Alps

Uredništvo je prispevek prejelo 10. oktobra 2017. 


\section{Uvod}

V Geografskem vestniku je v zadnjih dveh letnikih objavljenih več člankov, ki obravnavajo spreminjanje trendov pretokov slovenskih rek $\mathrm{v}$ zahodnem delu države $\mathrm{v}$ povezavi s podnebnimi spremembami. Tako za območje jadranskega povodja brez Posočja kot za Idrijsko hribovje je bilo ugotovljeno naraščanje povprečne letne temperature, zmanjševanje skupne letne višine padavin in upadanje srednjih letnih pretokov (Kovačič 2016; Kovačič, Kolega in Brečko Grubar 2016; Hrvatin in Zorn 2017).

V tem prispevku obravnavamo trende letnih pretokov rek, ki imajo povirja v slovenskem visokogorju. Obravnavane so reke: Soča, Koritnica, Tolminka, Mostnica, Sava Bohinjka, Sava Dolinka, Radovna, Tržiška Bistrica, Kokra, Kamniška Bistrica, Savinja in Meža (slika 1). Območje v grobem sovpada s submakroregijo alpska visokogorja (Perko 1998, 56), ki jo sestavljajo mezoregije Julijske Alpe, Kamniško-Savinjske Alpe, Zahodne Karavanke in Vzhodne Karavanke. Prvi dve sta razčlenjeni z globokimi ledeniško preoblikovanimi dolinami, na obrobjih pa ležijo izrazite zakrasele in gozdnate planote Pokljuka, Mežaklja, Jelovica, Velika planina, Dleskovška planota, Golte, Menina in Dobrovlje. Karavanke so izrazito podolgovato gorovje, visokogorsko le v skrajnem vršnem delu, ki se proti vzhodu nadaljuje v hribovje. Območje zavzema slabo šestino slovenskega ozemlja, s povprečno nadmorsko višino $1054,5 \mathrm{~m}$ in povprečnim naklonom 24,6 (Perko in Kladnik 1998, 31). Podnebje je pretežno gorsko (Ogrin 1996, 47). Povprečne temperature so v najhladnejšem mesecu pod $-3^{\circ} \mathrm{C}$ in v najtoplejšem mesecu nad $10^{\circ} \mathrm{C}$. Takšne razmere prevladujejo do nadmorske višine okoli $2000 \mathrm{~m}$, do koder seže tudi zgornja drevesna meja. Glede na padavinski režim lahko razdelimo pokrajino na dva dela: gorski svet v zahodni Sloveniji s submediteranskim režimom in letnimi padavinami od 1600 do $3000 \mathrm{~mm}$ ter gorski svet v severni Sloveniji z omiljenim celinskim padavinskim režimom in letnimi padavinami od 1100 do $1700 \mathrm{~mm}$ (Ogrin 1996, 52). Med kamninami prevladuje apnenec (na prek 50 \% območja), gozdnatost pa presega $70 \%$ (Petek 2005, 42, 132).

\section{Hidrološki režim in podnebne spremembe}

Številne raziskave kažejo, da podnebne spremembe vplivajo na hidrološki režim (glej literaturo v Arnell in Gosling 2013, 351). V članku obravnavamo slovenske Alpe, kjer ima na hidrološki režim velik vpliv taljenje snega.

V Švici v splošnem ugotavljajo povečanje letnih pretokov, predvsem na račun večjega odtoka pozimi, spomladi in jeseni. Zimsko povečanje povezujejo s spremembo snežnih padavin v dežne zaradi višjih temperatur, prav tako pa višje spomladanske pretoke povezujejo $\mathrm{z}$ višjimi temperaturami in posledično zgodnejšim taljenjem snega (Birsan in ostali 2005, 326). Topogledno v porečjih severno od Alp (Ren, Donava) ugotavljajo, da so se v zadnjem stoletju spomladanski pretoki časovno prestavili za več kot dva tedna, južno od Alp (Rona, Pad) pa za več kot tri tedne (Zampieri in ostali 2015, 230). V Avstriji napovedujejo višje pretoke pozimi kot posledico zgodnejšega taljenja snega, v toplejšem delu leta pa posledično nižje pretoke poleti (Goler in ostali 2016, 621). Povečanje zimskega in jesenskega pretoka opažajo tudi v celinskem delu Hrvaške, zmanjšane pretoke pa poleti (Čanjevec in Orešić 2018, 8). V severni Italiji se zimski pretoki zmanjšujemo pod $1800 \mathrm{~m}$ nadmorske višine, višje pa se povečujejo; spomladanski in poletni pretoki se zmanjšujejo (Bocchiola 2014, 51). Večina italijanskih alpskih rek kaže nižje letne pretoke (povprečno $-0,1491 / \mathrm{s} \mathrm{s} \mathrm{km}^{2}$ na leto oziroma približno $-13,4 \mathrm{l} / \mathrm{s} \mathrm{s} \mathrm{km}^{2} \mathrm{v} 90$ letih) (Bocchiola 2014, 61).

Po enem izmed globalnih podnebnih scenarijev naj bi se povprečni odtok do leta 2050 povečal na skoraj polovici kopnega, zmanjšal pa na dobri tretjini. V Evropi naj bi narasel predvsem v višjih zemljepisnih širinah, zmanjšal pa v Srednji Evropi in v Sredozemlju (Arnell in Gosling 2013, 363-364).

Niso pa zgolj spremembe temperatur in padavin tiste, ki vplivajo na hidrološki režim. Spremembe temperatur vplivajo na izhlapevanje, ki naj bi se tekom 21. stoletja zaradi nekaj stopinj višjih temperatur 
povečalo za prek $200 \mathrm{~mm}$ /leto (Goler in ostali 2016, 624). Na območju Alp naj bi se temperature do konca 21. stoletja dvignile za $+3,9^{\circ} \mathrm{C}$, kar je več kot v Evropi kot celoti $\left(+3,3^{\circ} \mathrm{C}\right)$ (Janža 2013, 1026). Pri spreminjanju hidrološkega režima pa ne smemo pozabiti na neposredne človeške vplive: spremembe rabe tal, regulacijske posege, gradnjo pregrad, urbanizacijo in namakanje (Ulaga 2002, 111; Bormann 2010, 261; Zampieri in ostali 2015, 222; Šraj, Menih in Bezjak 2016), pa tudi na dolžino merilnih nizov (Bezjak, Brilly in Šraj 2016).

\subsection{Slovenske reke}

Pretekle raziskave povprečnih letnih pretokov slovenskih rek so pokazale, da je bil »... statistično značilen regionalni trend odkrit predvsem pri pretokih rek v severozahodnem delu ... « države, kje se »...povprečni letni odtok ...v zadnjih petdesetih letih zmanjšuje ... " (Frantar, Kobold in Ulaga 2008, 50; glej tudi Uhan 2007, 164; Ulaga, Kobold in Frantar 2008a; 2008b; Kobold, Dolinar in Frantar 2012, 15).

"Trend srednjih letnih pretokov [v obdobju 1971-2000, opomba avtorjev] kaže na zmanjševanje letne količine vode v vseh pokrajinskih enotah Slovenije « (Frantar, Kobold in Ulaga 2008, 54). Padajoči trend srednjih letnih pretokov so ugotovili tudi za obdobje 1955-1999, ko naj bi pretoki povprečno upadli za dobrih 18 \% (Ulaga 2002, 99-100). Upadanje je pri večini vodotokov v Sloveniji ugotovil tudi Makor $(2016,77,88)$, ki izpostavi, da »... v poletnih mesecih pretok upada v primerjavi z ostalim letom ... ter da se decembra pretok povečuje ... «. Do nekoliko drugačnih sklepov pa so prišli Šrajeva, Menih in Bezjak (2016), katerih rezultati na ravni Slovenije ne kažejo nekega splošnega trenda naraščanja ali upadanja srednjih letnih pretokov.

Nekatere projekcije kažejo, da se bodo pretoki v Slovenji v prihodnje še zmanjševali - ob dvigu temperature $\mathrm{za}+1^{\circ} \mathrm{C}$ ter hkratnemu padcu padavin za desetino, naj bi se pretoki v Posavju zmanjšali za slabo četrtino, v Posočju pa za dobro šestino, ob dvigu temperatur za $+2,5^{\circ} \mathrm{C}$ pa naj bi se pretoki v Posavju zmanjšali za tretjino, v Posočju pa za slabo četrtino (Kobold 2007, 105).

V obdobju 1971-2000 so upadali tudi trendi največjih letnih pretokov, a so imeli manjšo statistično značilnost kot povprečni letni pretoki. Predvsem gorska porečja so kazala tudi upadanje minimalnih letnih pretokov (Frantar, Kobold in Ulaga 2008, 56; Ulaga, Kobold in Frantar 2008a, 5; Kobold, Dolinar in Frantar 2012, 16-17). Statistično značilni negativni trendi malih pretokov v obdobju 1971-2000 so bili na Meži, Savi Bohinjki, Savi v Radovljici, Savinji, Soči v Kršovcu in Radovni (Ulaga, Kobold in Frantar 2008b, 12).

V obdobju 1955-1999 je bil na območju zgornjega toka Save srednji letni pretok nadpovprečno padajoč, upadali pa so tudi minimalni letni pretoki. Nadpovprečno upadanje srednjega letnega pretoka je imela tudi Kokra, manjše upadanje pa je kazala Kamniška Bistrica. Močan trend upadanja srednjega letnega pretoka sta kazali Savinja v zgornjem toku ter Koritnica, povprečno upadanje pa Soča (Ulaga 2002, 107, 109)

\subsection{Temperature in padavine}

Od sredine 19. stoletja, ko se je končala »mala ledena doba«, so se temperature v Evropi in širše zviševale. V 20. stoletju se je globalna temperatura zvišala za $0,74 \pm 0,18^{\circ} \mathrm{C}(1906-2005)$. Naraščanje temperatur $\mathrm{v}$ drugi polovici stoletja se je skoraj podvojijo v primerjavi s celotnim stoletjem $\left(0,13 \pm 0,03^{\circ} \mathrm{C} /\right.$ desetletje v primerjavi z $0,07 \pm 0,02^{\circ} \mathrm{C}$ /desetletje; Trenberth in ostali 2007). V Evropi so se v 20. stoletju maksimalne in minimalne temperature pozimi zvišale za $1^{\circ} \mathrm{C}$ na 100 let, poleti pa $\mathrm{za} 0,8^{\circ} \mathrm{C}$ na 100 let (Milošević in ostali 2017,2). V Slovenji se je povprečna temperatura zraka v drugi polovici 20. stoletja (1956-2005) statistično značilno povečala za $1,4 \pm 0,6^{\circ} \mathrm{C}$, najbolj v mestih in manj na podeželju (preglednica 1). Projekcije za 21. stoletje kažejo dvig temperature zraka v hladni polovici leta za približno $3^{\circ} \mathrm{C}\left(\operatorname{razpon}\right.$ od 1,5 do $\left.7^{\circ} \mathrm{C}\right)$ in v topli polovici leta za $3,5^{\circ} \mathrm{C}\left(\operatorname{razpon}\right.$ od $\left.1,5 \operatorname{do} 8^{\circ} \mathrm{C}\right)($ Kajfež-Bogataj 2006, 171-172). 
Spremembe količine padavin na večjem delu slovenskega ozemlja niso statistično značilne (Kajfež-Bogataj 2006, 172). Kljub temu so opazni trendi, ki nakazujejo manjše količine padavin (preglednica 2), na primer v Ljubljani od $-36 \mathrm{~mm}$ do $-43 \mathrm{~mm}$ na 100 let, v Mariboru $-40 \mathrm{~mm}$ na 100 let in Trstu -80 mm na 100 let (Ogrin 2003, 121; Žiberna 2011, 109-110).

V Sloveniji se količina padavin spreminja tudi sezonsko. »... Jeseni se količina padavin veča skoraj po vsej državi z izjemo manjših predelov na jugovzhodu države in na Koroškem. Pozimi smo zaznali dvojnost: $v$ zahodni Sloveniji ter na Koroškem in Pohorju se količina zmanjšuje, v vzhodni polovici pa sprememb ni. Spomladi je opaziti dokaj enoten trend zmanjševanja padavin po vsej državi razen $v$ vzhodni Štajerski, Prekmurju in Goričkem. Poleti je po vsej državi padavin manj, izjema so višji predeli Alp, kjer ni opaziti sprememb. Padavinski režim se spreminja, jesenski višek postaja bolj izrazit, medtem ko se v ostalih mesecih količina padavin zmanjšuje, kar odločujoče vpliva tudi na količine pretokov v rekah ..." (Kobold, Dolinar in Frantar 2012, 10).

Poleg padavinskega režima na pretok vpliva tudi snežna odeja. V obdobju 1971-2000 so zabeležili statistično značilen upad na zahodnem robu Alpsko-Dinarske pregrade, za celotno državo pa je bilo ugotovljeno manjšanje akumulacije padavin v snežni odeji (Kobold, Dolinar in Frantar 2012, 10-11). V Ljubljani se je v obdobju 1950-2009 število dni s snežno odejo zmanjševalo za tri dni na desetletje, na ravni države pa za 2 do 4 dni na desetletje (Dolinar 2010, 4, 12).

Preglednica 1: Izbrani podatki o naraščanju temperatur v Sloveniji (+ naraščajoči trend, - padajoči trend).

\begin{tabular}{|c|c|c|}
\hline obdobje & sprememba temperature & vir \\
\hline $1951-2000$ & $+1,1 \pm 0,6^{\circ} \mathrm{C}$ & Sušnik 2004, 13 \\
\hline $1951-2007$ & $\begin{array}{l}\mathbf{+ 0 , 1 5 - 0 , 2 9}{ }^{\circ} \mathbf{C} / \text { desetletje } \\
\text { Pomlad: }+0,3-0,4^{\circ} \mathrm{C} / \text { desetletje } \\
\text { Poletje: }+0,3-0,4^{\circ} \mathrm{C} / \text { desetletje } \\
\text { Jesen: brez posebnega trenda } \\
\text { Zima: }+0,2-0,3^{\circ} \mathrm{C} / \text { desetletje }\end{array}$ & De Luis in ostali 2014, 1804; Climate ... 2017 \\
\hline $1956-2005$ & $\begin{array}{l}+\mathbf{1}, \mathbf{4} \pm \mathbf{0 , 6} \mathbf{6}^{\circ} \mathrm{C} \\
\text { Topla polovica leta: } \\
\left.+3,5^{\circ} \mathrm{C} \text { (razpon: } 1,5-8^{\circ} \mathrm{C}\right) \\
\text { Hladna polovica leta: } \\
\left.+3^{\circ} \mathrm{C} \text { (razpon: } 1,5-7^{\circ} \mathrm{C}\right)\end{array}$ & Kajfež-Bogataj 2006, 171-172 \\
\hline 1961-2011 & $\begin{array}{l}\text { Povprečne letne: }+\mathbf{1}, \mathbf{4}-\mathbf{2}, 4^{\circ} \mathrm{C} / \mathbf{5 1} \text { let } \\
\text { Maksimalne letne: }+1,3-2,4^{\circ} \mathrm{C} / 51 \text { let } \\
\text { Minimalne letne: }+1,7-2,9^{\circ} \mathrm{C} / 51 \text { let }\end{array}$ & Milošević, Savić in Žiberna 2013, 7 \\
\hline 1961-2011 & $+0,3-0,4^{\circ} \mathrm{C} /$ desetletje & Vertačnik in ostali 2015, 4015; Climate ... 2017 \\
\hline 1979-2008 & $+0,6^{\circ} \mathrm{C} / 100$ let & Dolinar in Vertačnik 2010, 38 \\
\hline $\begin{array}{l}1991-2007 \text { glede } \\
\text { na } 1961-1990\end{array}$ & $+0,7-1,4^{\circ} \mathrm{C}$ & Kajfež-Bogataj in ostali 2010, 100 \\
\hline 1963-2014 & $\begin{array}{l}\text { Povprečne letne: }+\mathbf{0}, \mathbf{3}-\mathbf{0 , 5} \mathbf{5}^{\circ} \mathbf{C} \text { desetletje } \\
\text { Pomlad: }+0,4-0,6^{\circ} \mathrm{C} / \text { desetletje } \\
\text { Poletje: }+0,4-0,7^{\circ} \mathrm{C} / \text { desetletje } \\
\text { Jesen: }+0,1-0,3^{\circ} \mathrm{C} / \text { desetletje } \\
\text { Zima: }+0,2-0,6^{\circ} \mathrm{C} / \text { desetletje }\end{array}$ & Milošević in ostali 2017,7 \\
\hline
\end{tabular}


Preglednica 2: Izbrani podatki o spreminjanju padavin, na primeru treh večjih mest $v$ Sloveniji in zamejstvu (+ naraščajoči trend, - padajoči trend).

\begin{tabular}{|c|c|c|c|}
\hline kraj & obdobje & sprememba padavin & vir \\
\hline Ljubljana & $1851-2002$ & $\begin{array}{l}\text { Leto: }-\mathbf{3 6} \mathbf{~ m m} / \mathbf{1 0 0} \text { let } \\
\text { Pomlad: }-1 \mathrm{~mm} / 100 \text { let } \\
\text { Poletje: }+11 \mathrm{~mm} / 100 \text { let } \\
\text { Jesen: }-38 \mathrm{~mm} / 100 \text { let } \\
\text { Zima: }+11 \mathrm{~mm} / 100 \text { let }\end{array}$ & Ogrin 2003,$121 ; 2004,49$ \\
\hline Ljubljana & $1865-2010$ & $\begin{array}{l}\text { Leto: }-\mathbf{4 3}, \mathbf{1 7} \mathrm{mm} / \mathbf{1 0 0} \text { let } \\
\text { Pomlad: }-10,39 \mathrm{~mm} / 100 \text { let } \\
\text { Poletje: }-20,97 \mathrm{~mm} / 100 \text { let } \\
\text { Jesen: }-19,16 \mathrm{~mm} / 100 \text { let } \\
\text { Zima: }+8,36 \mathrm{~mm} / 100 \text { let }\end{array}$ & Žiberna 2011, 109-110 \\
\hline Ljubljana & 1961-2011 & $-273 \mathrm{~mm}$ & Milošević, Savić in Žiberna 2013, 8 \\
\hline Ljubljana & 1950-2009 & $\begin{array}{l}\text { Leto: }-\mathbf{1 6} \mathbf{m m} / \mathbf{1 0} \text { let } \\
\text { Pomlad: }-8 \mathrm{~mm} / 10 \text { let } \\
\text { Poletje: }-7 \mathrm{~mm} / 10 \text { let } \\
\text { Jesen: }+14 \mathrm{~mm} / 10 \text { let } \\
\text { Zima: }-16 \mathrm{~mm} / 10 \text { let }\end{array}$ & Dolinar 2010, 4 \\
\hline Ljubljana & $\begin{array}{l}\text { 1988-2002 } \\
\text { v primerjavi } \\
\text { z 1961-1990 }\end{array}$ & $\begin{array}{l}\text { Leto: }-69 \mathrm{~mm} \\
\text { Pomlad: }-48 \mathrm{~mm} \\
\text { Poletje: }-37 \mathrm{~mm} \\
\text { Jesen: }+74 \mathrm{~mm} \\
\text { Zima: }-52 \mathrm{~mm}\end{array}$ & Ogrin 2003,127 \\
\hline Maribor & $1876-2010$ & $\begin{array}{l}\text { Leto: }-\mathbf{3 9}, 75 \mathrm{~mm} / \mathbf{1 0 0} \text { let } \\
\text { Pomlad: }-34,23 \mathrm{~mm} / 100 \text { let } \\
\text { Poletje: }-3,54 \mathrm{~mm} / 100 \text { let } \\
\text { Jesen: }-15,72 \mathrm{~mm} / 100 \text { let } \\
\text { Zima: }+1,35 \mathrm{~mm} / 100 \text { let }\end{array}$ & $\begin{array}{l}\text { Žiberna 2011a, 111, 113; } \\
\text { Žiberna 2011b, } 28\end{array}$ \\
\hline Maribor & $1961-2011$ & $-139,2 \mathrm{~mm}$ & Milošević, Savić in Žiberna 2013, 8 \\
\hline Trst & $1851-2002$ & 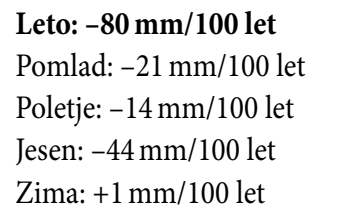 & Ogrin 2003,$121 ; 2004,49$ \\
\hline Trst & $\begin{array}{l}\text { 1988-2002 } \\
\text { v primerjavi } \\
\text { z 1961-1990 }\end{array}$ & $\begin{array}{l}\text { Leto: }+\mathbf{3 2} \mathbf{m m} \\
\text { Pomlad: }-5 \mathrm{~mm} \\
\text { Poletje: }-15 \mathrm{~mm} \\
\text { Jesen: }+96 \mathrm{~mm} \\
\text { Zima: }-42 \mathrm{~mm}\end{array}$ & Ogrin 2003,127 \\
\hline
\end{tabular}




\section{Metode}

Za ugotavljanje trenda spreminjanja izbranih podnebnih in hidroloških spremenljivk (preglednica 3) v obdobju od 1961 do 2010 smo na izbranih vodomernih, temperaturnih in padavinskih postajah (preglednici 4 in 5; slika 1) uporabili Mann-Kendallov test ter Theil-Senovo cenilko, krajše imenovano tudi Senov naklon. Mann-Kendallov test je neparametričen test za ugotavljanje monotonega trenda. Ni občutljiv na podatkovne osamelce in temelji na testni statistiki. Pozitivna vrednost testne statistike označuje naraščajoč trend, negativna vrednost testne statistike pa kaže na padajoč trend (Kraner Šumenjak in Šuštar 2011). Senov naklon je najpogosteje uporabljani neparametrični test za ugotavljanje linearnega časovnega trenda (Kraner Šumenjak in Šuštar 2011). V primerjavi z linearno regresijo je Senov naklon bistveno bolj natančen pri asimetrično porazdeljenih podatkih in pri normalno porazdeljenih podatkih daje povsem primerljive rezultate metodi najmanjših kvadratov (Kovačič 2016, 10; Kovačič, Kolega in Brečko Grubar 2016, 24).

Pri izračunih vrednosti Mann-Kendallovega testa in Senovega naklona smo si pomagali s prosto dostopnim programskim orodjem MAKESENS (Mann-Kendall test for trend and Sen's slope estimates) 1.0 (medmrežje 1; Salmi in ostali 2002).

V preglednicah hidroloških in podnebnih spremenljivk so poleg vrednosti Mann-Kendallovega testa in Senovega naklona predstavljene še vrednosti ravni zaupanja, (začetnega) trendnega stanja leta 1961, (končnega) trendnega stanja leta 2010 ter absolutne in relativne trendne razlike.

Raven zaupanja je v statistiki verjetnost, da izračunani interval zaupanja vključuje vrednost ocenjevanega parametra. Višja raven zaupanja v našem primeru pomeni večjo verjetnost, da ugotovljeni trend naraščanja ali upadanja izbrane spremenljivke dejansko obstaja.

Začetno trendno stanje leta 1961 je vrednost izbrane spremenljivke za leto 1961, ki smo jo odčitali na trendni premici, končno trendno stanje leta 2010 pa je vrednost izbrane spremenljivke za leto 2010, ki smo jo prav tako odčitali na trendni premici. Absolutna trendna razlika je razlika med končnim in začetnim trendnim stanjem, relativna trendna razlika pa je razlika med končnim in začetnim trendnim stanjem izražena v odstotkih.

Trendno vrednost za izbrano leto lahko izračunamo po enačbi:

trendna vrednost za leto $\mathrm{x}=$ Senov naklon $\cdot($ trendno leto $\mathrm{x}-$ začetno trendno leto $)+$ začetna trendna vrednost.

Preglednica 3: Obravnavane hidrološke in podnebne spremenljivke.

\begin{tabular}{ll} 
hidrološke spremenljivke & $\begin{array}{l}\text { absolutni minimalni pretok } \\
\text { povprečni srednji pretok } \\
\text { absolutni maksimalni pretok }\end{array}$ \\
\hline podnebne spremenljivke & povprečna letna temperatura \\
& količina letnih padavin \\
& dnevi s padavinami nad $0,1 \mathrm{~mm}$ \\
& dnevi s snežno odejo
\end{tabular}

Slika 1: Lokacije temperaturnih, padavinskih in vodomernih postaj, obravnavanih $v$ analizi. str. 16 


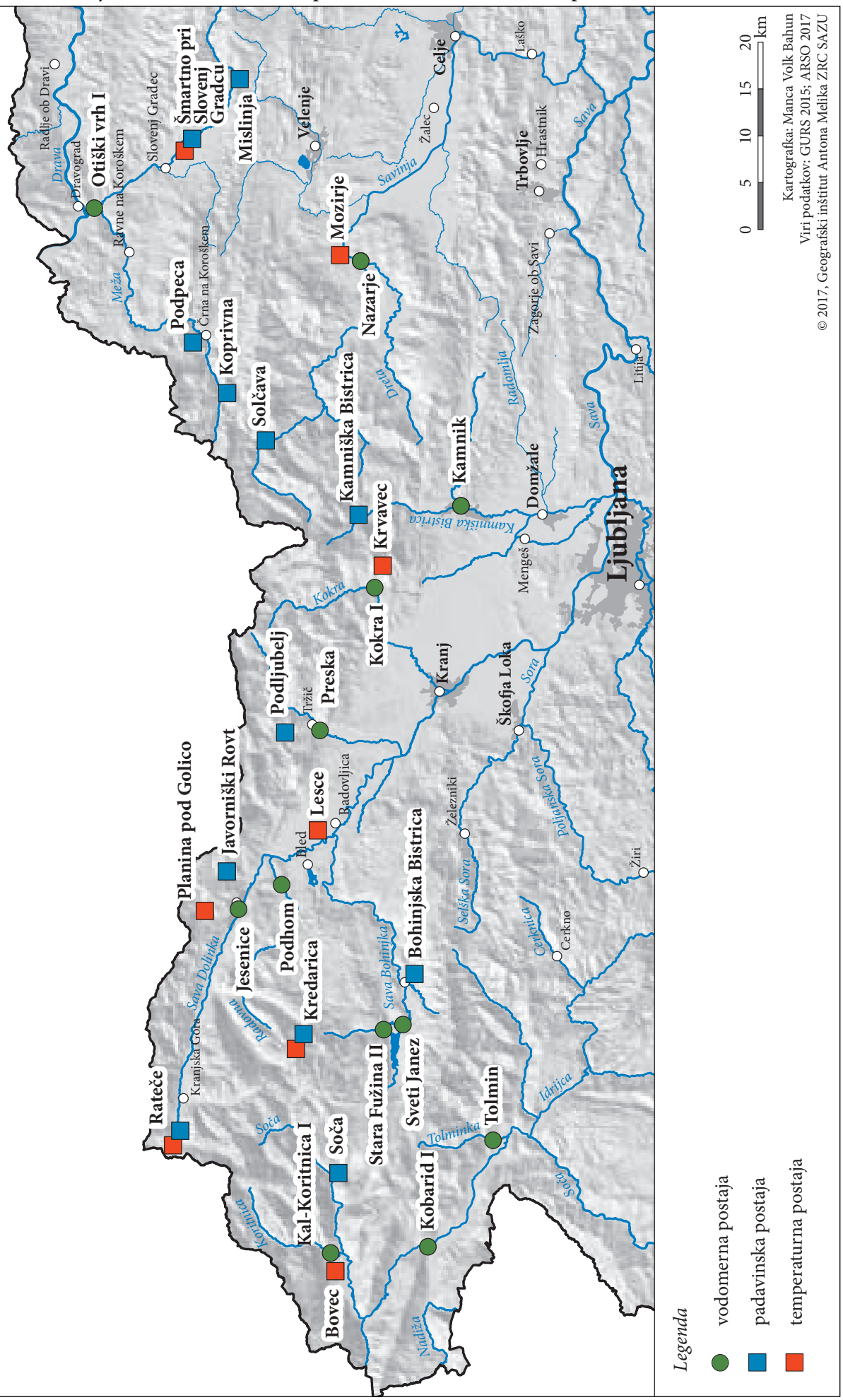




\section{Podatki}

\subsection{Hidrološke spremenljivke}

Podatke o hidroloških spremenljivkah smo pridobili na Agenciji Republike Slovenije za okolje (Arhiv hidroloških ... 2017). V analizo smo vključili dvanajst postaj iz slovenskih Alp (preglednica 4; slika 1). Uporabili smo podatke s postaj z več desetletnim nizom meritev.

Preglednica 4: Obravnavane vodomerne postaje s časovnimi nizi meritev.

\begin{tabular}{lllccc}
\hline $\begin{array}{l}\text { vodomerna } \\
\text { postaja }\end{array}$ & vodotok & občina & $\begin{array}{c}\text { nadmorska } \\
\text { višina }(\mathrm{m})\end{array}$ & $\begin{array}{c}\text { časovni } \\
\text { niz }\end{array}$ & $\begin{array}{c}\text { število letnih } \\
\text { meritev }\end{array}$ \\
\hline Otiški Vrh I & Meža & Dravograd & 334 & $1961-2010$ & 50 \\
Jesenice & Sava Dolinka & Jesenice & 566 & $1961-2010$ & 50 \\
Podhom & Radovna & Gorje & 566 & $1961-2010$ & 50 \\
Sveti Janez & Sava Bohinjka & Bohinj & 525 & $1961-2010$ & 50 \\
Stara Fužina II & Mostnica & Bohinj & 527 & $1961-2006$ & 46 \\
Preska & Tržžška Bistrica & Tržič & 489 & $1961-2010$ & 49 \\
Kokra I & Kokra & Preddvor & 523 & $1961-2010$ & 50 \\
Kamnik I & Kamniška Bistrica & Kamnik & 371 & $1961-2006$ & 46 \\
Nazarje & Savinja & Nazarje & 337 & $1961-2010$ & 50 \\
Kobarid I & Soča & Kobarid & 195 & $1961-2010$ & 50 \\
Kal-Koritnica & Koritnica & Bovec & 405 & $1961-2010$ & 49 \\
Tolmin & Tolminka & Tolmin & 168 & $1961-2010$ & 45 \\
\hline
\end{tabular}

\subsection{Podnebne spremenljivke}

Podatke o podnebnih spremenljivkah smo pridobili na Agenciji Republike Slovenije za okolje (Arhiv meteoroloških ... 2017). V analizo smo vključili osem temperaturnih in dvanajst padavinskih postaj iz slovenskih Alp (preglednica 5; slika 1). Uporabili smo podatke s postaj z več desetletnim nizom meritev.

Preglednica 5: Obravnavane vremenske postaje s časovnimi nizi meritev.

\begin{tabular}{|c|c|c|c|c|c|}
\hline & $\begin{array}{l}\text { vremenska } \\
\text { postaja }\end{array}$ & občina & $\begin{array}{l}\text { nadmorska } \\
\text { višina (m) }\end{array}$ & $\begin{array}{c}\text { časovni } \\
\text { niz }\end{array}$ & $\begin{array}{l}\text { število letnih } \\
\text { meritev }\end{array}$ \\
\hline \multirow[t]{8}{*}{$\begin{array}{l}\text { temperaturna } \\
\text { postaja }\end{array}$} & $\begin{array}{l}\text { Šmartno pri } \\
\text { Slovenj Gradcu }\end{array}$ & Slovenj Gradec & 444 & 1961-2010 & 50 \\
\hline & Mozirje & Mozirje & 340 & 1961-2010 & 50 \\
\hline & Krvavec & $\begin{array}{l}\text { Cerklje na } \\
\text { Gorenjskem }\end{array}$ & 1740 & 1961-2010 & 47 \\
\hline & Lesce & Radovljica & 515 & 1961-2010 & 50 \\
\hline & $\begin{array}{l}\text { Planina } \\
\text { pod Golico }\end{array}$ & Jesenice & 947 & 1961-2010 & 50 \\
\hline & Rateče & Kranjska Gora & 864 & 1961-2010 & 50 \\
\hline & Kredarica & Kranjska Gora & 2513 & 1961-2010 & 50 \\
\hline & Bovec & Bovec & 450 & 1961-2010 & 50 \\
\hline
\end{tabular}




\begin{tabular}{lllccc}
\hline & $\begin{array}{l}\text { vremenska } \\
\text { postaja }\end{array}$ & občina & $\begin{array}{c}\text { nadmorska } \\
\text { višina }(\mathrm{m})\end{array}$ & $\begin{array}{c}\text { časovni } \\
\text { niz }\end{array}$ & $\begin{array}{c}\text { število letnih } \\
\text { meritev }\end{array}$ \\
\hline $\begin{array}{l}\text { padavinska } \\
\text { postaja }\end{array}$ & Mislinja & Mislinja & 589 & $1961-2010$ & 50 \\
& $\begin{array}{l}\text { Šmartno pri } \\
\text { Slovenj Gradcu }\end{array}$ & Slovenj Gradec & 444 & $1961-2010$ & 50 \\
& Podpeca & Črna na Koroškem & 950 & $1961-2010$ & 49 \\
& Koprivna & Črna na Koroškem & 840 & $1961-2010$ & 50 \\
& Solčava & Solčava & 658 & $1961-2010$ & 50 \\
& Kamniška Bistrica & Kamnik & 610 & $1961-2010$ & 48 \\
& Podljubelj & Tržič & 679 & $1961-2010$ & 49 \\
& Javorniški Rovt & Jesenice & 940 & $1961-2010$ & 50 \\
& Rateče & Kranjska Gora & 864 & $1961-2010$ & 50 \\
& Bohinjska Bistrica & Bohinj & 507 & $1961-2010$ & 49 \\
& Kredarica & Kranjska Gora & 2513 & $1961-2010$ & 50 \\
& Soča & Bovec & 487 & $1961-2010$ & 50 \\
\hline
\end{tabular}

\section{Rezultati}

\subsection{Hidrološke spremenljivke}

V okviru hidroloških spremenljivk smo obravnavali (preglednica 3): (1) trende absolutnih minimalnih letnih pretokov, (2) trende povprečnih srednjih letnih pretokov in (3) trende absolutnih maksimalnih letnih pretokov.

\subsubsection{Absolutni minimalni letni pretoki}

Trendi absolutnih minimalnih letnih pretokov v obdobju od 1961 do 2010 so pri desetih alpskih vodotokih od dvanajstih izrazito padajoči (preglednica 6, slika 2). Trendna razlika je skromna in zanemarljiva le na Savi Bohinjki (vodomerna postaja (v. p.) Sveti Janez) in Soči (v. p. Kobarid I), pri vseh ostalih rekah pa presega vsaj $15 \%$.

Raven zaupanja je zelo spremenljiva. Na sedmih vodotokih (Radovna, Sava Bohinjka, Mostnica, Kokra, Soča, Koritnica in Tolminka) ne presega $90 \%$, pri preostalih petih vodotokih (Meža, Sava Dolinka, Tržiška Bistrica, Kamniška Bistrica in Savinja) pa dosega vsaj 99,0 \%.

Z izjemo Save Bohinjke so se absolutni minimalni pretoki v obravnavanem obdobju (1961-2010) zmanjšali za 0,09 do $1,85 \mathrm{~m}^{3} / \mathrm{s}$ oziroma za 90 do $1850 \mathrm{l} / \mathrm{s}$. V relativnem smislu beležijo Radovna, Mostnica, Kokra, Savinja in Koritnica upad od 15 do 25 \%, pri Meži, Savi Dolinki (slika 2), Tržiški Bistrici, Kamniški Bistrici in Tolminki pa upad celo koleba med 35 in 40 \%. Tako v absolutnem kot relativnem smislu beleži največji upad Meža pri v. p. Otiški Vrh I, katere absolutni minimalni pretok se je v obdobju od 1961 do 2010 zmanjšal za 1,85 m³/s oziroma za $39 \%$.

\subsubsection{Povprečni srednji letni pretoki}

Trendi povprečnih srednjih letnih pretokov v obdobju od 1961 do 2010 so na vseh dvanajstih vodotokih oziroma vodomernih postajah padajoči (preglednica 7, slika 3). Raven zaupanja je spremenljiva. Pri Meži, Mostnici in Kokri dosega ali presega 99\%, pri Savi Dolinki in Savi Bohinjki je 95 \%, v vseh preostalih primerih (Radovna, Tržiška Bistrica, Kamniška Bistrica, Savinja, Soča, Koritnica in Tolminka) pa je le $90 \%$ ali celo nižja. 
Preglednica 6: Trendi absolutnih minimalnih letnih pretokov v obdobju od 1961 do 2010.

\begin{tabular}{|c|c|c|c|c|c|c|c|c|}
\hline \multirow[t]{2}{*}{$\begin{array}{l}\text { vodomerna } \\
\text { postaja }\end{array}$} & \multirow[t]{2}{*}{ vodotok } & $\begin{array}{l}\text { Mann- } \\
\text { Kendallov } \\
\text { test }\end{array}$ & $\begin{array}{c}\text { raven } \\
\text { zaupanja }\end{array}$ & $\begin{array}{l}\text { Senov } \\
\text { naklon }\end{array}$ & $\begin{array}{c}\text { trendno } \\
\text { stanje } \\
1961\end{array}$ & $\begin{array}{c}\text { trendno } \\
\text { stanje } \\
2010\end{array}$ & $\begin{array}{c}\text { trendna } \\
\text { razlika } \\
1961- \\
2010\end{array}$ & $\begin{array}{c}\text { trendna } \\
\text { razlika } \\
1961- \\
2010\end{array}$ \\
\hline & & Z & $\%$ & Q & $\mathrm{m}^{3} / \mathrm{s}$ & $\mathrm{m}^{3} / \mathrm{s}$ & $\mathrm{m}^{3} / \mathrm{s}$ & $\%$ \\
\hline Otiški Vrh I & Meža & $-4,07$ & 99,9 & $-0,038$ & 4,74 & 2,89 & $-1,85$ & $-39,06$ \\
\hline Jesenice (slika 2) & Sava Dolinka & $-3,60$ & 99,9 & $-0,036$ & 4,65 & 2,89 & $-1,76$ & $-37,84$ \\
\hline Podhom & Radovna & $-1,26$ & pod 90,0 & $-0,005$ & 1,72 & 1,46 & $-0,26$ & $-15,08$ \\
\hline Sveti Janez & Sava Bohinjka & 0,05 & pod 90,0 & 0,000 & 0,81 & 0,81 & 0,00 & $-0,49$ \\
\hline Stara Fužina II & Mostnica & $-0,90$ & pod 90,0 & $-0,002$ & 0,43 & 0,34 & $-0,09$ & $-20,81$ \\
\hline Preska & Tržiška Bistrica & $-3,07$ & 99,0 & $-0,018$ & 2,50 & 1,61 & $-0,89$ & $-35,67$ \\
\hline Kokra I & Kokra & $-1,82$ & 90,0 & $-0,007$ & 1,45 & 1,10 & $-0,35$ & $-23,90$ \\
\hline Kamnik I & Kamniška Bistrica & $-3,51$ & 99,9 & $-0,020$ & 2,26 & 1,38 & $-0,88$ & $-38,87$ \\
\hline Nazarje & Savinja & $-2,78$ & 99,0 & $-0,018$ & 3,67 & 2,78 & $-0,89$ & $-24,21$ \\
\hline Kobarid I & Soča & $-0,15$ & pod 90,0 & $-0,002$ & 7,81 & 7,70 & $-0,11$ & $-1,42$ \\
\hline Kal-Koritnica & Koritnica & $-1,63$ & pod 90,0 & $-0,009$ & 2,33 & 1,90 & $-0,43$ & $-18,49$ \\
\hline Tolmin & Tolminka & $-1,84$ & 90,0 & $-0,011$ & 1,48 & 0,94 & $-0,54$ & $-36,64$ \\
\hline
\end{tabular}

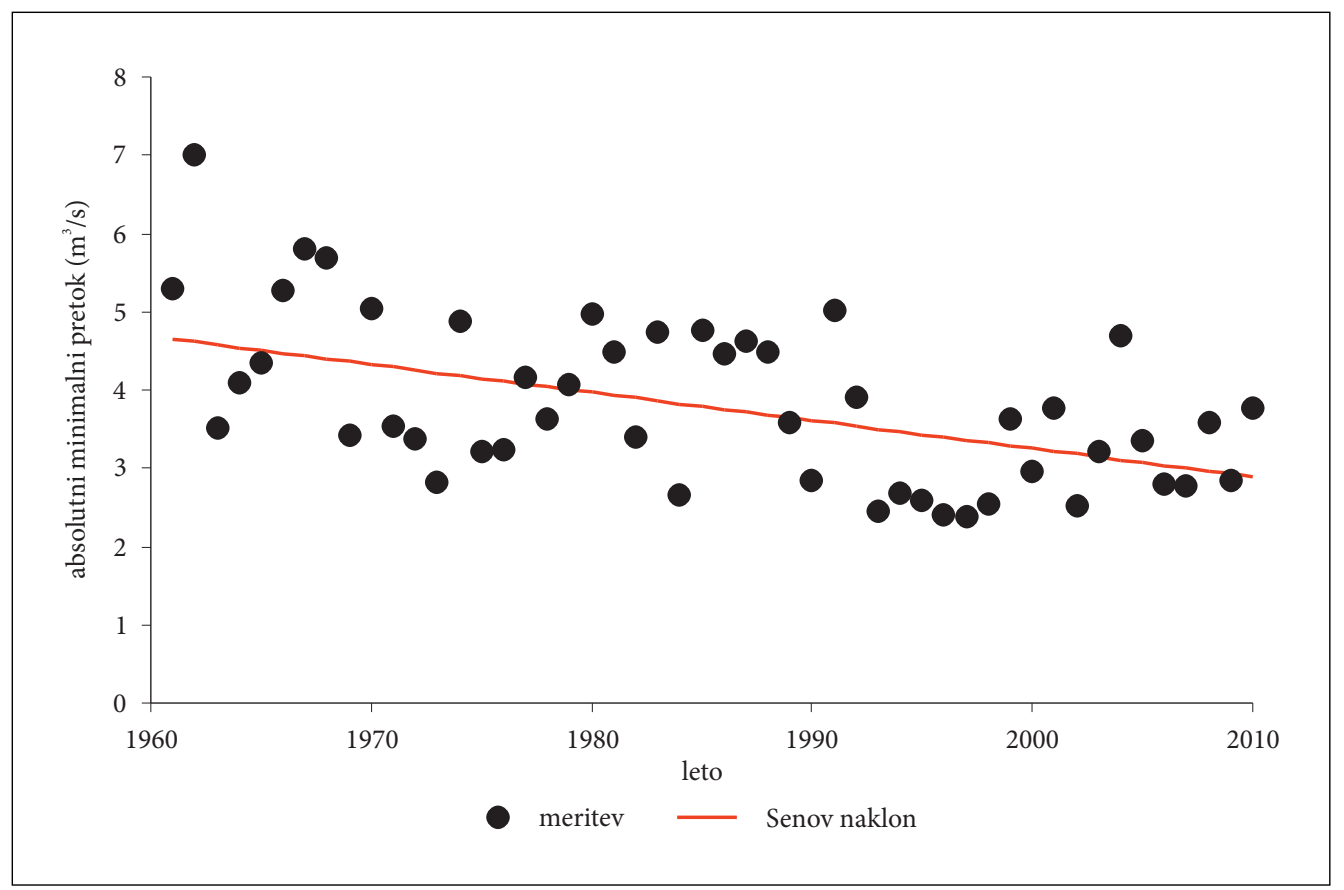

Slika 2: Trend absolutnih minimalnih letnih pretokov Save Dolinke pri vodomerni postaji Jesenice v obdobju od 1961 do 2010. 
Srednji letni pretoki so se v obravnavanem obdobju zmanjšali za 0,39 do $4,33 \mathrm{~m}^{3} / \mathrm{s}$. V relativnem smislu beleži večina vodotokov upad od 15 do $25 \%$, manj kot $10 \%$ le Savinja in Tolminka. Absolutna trendna razlika povprečnih srednjih pretokov v obdobju od 1961 do 2010 je največja na Soči pri v.p. Kobarid I, kjer je pretok upadel za $4,33 \mathrm{~m}^{3} / \mathrm{s}$, največjo relativno trendno razliko pa beleži Mostnica pri v. p. Stara Fužina II, kjer je pretok upadel za 27,56\%.

\subsubsection{Absolutni maksimalni letni pretoki}

Trendi absolutnih maksimalnih letnih pretokov v obdobju od 1961 do 2010 so na osmih vodotokih padajoči (Meža, Radovna, Sava Bohinjka, Mostnica (slika 4), Kokra, Kamniška Bistrica, Savinja in Koritnica), na preostalih štirih pa je trend naraščajoč (Sava Dolinka, Tržiška Bistrica, Soča in Tolminka) (preglednica 8). Raven zaupanja je nizka, saj na desetih obravnavanih vodotokih oziroma vodomernih postajah ne dosega niti 90 \%. Izjemi sta Mostnica pri v. p. Stara Fužina II in Kamniška Bistrica pri v. p. Kamnik I z $99 \%$ ravnijo zaupanja.

Absolutni maksimalni letni pretoki so se v obravnavanem obdobju (1961-2010) najbolj zmanjšali na Mostnici pri v. p. Stara Fužina II in sicer za 49,25 m³/s oziroma 57,4 \% ter na Kamniški Bistrici pri v. p. Kamnik I za $58,57 \mathrm{~m}^{3} / \mathrm{s}$ oziroma $48,9 \%$. Nekoliko nižji delež trendnega upada beležijo Meža pri v. p. Otiški Vrh I (-29,94 m³/s oziroma -20,7 \%), Kokra pri v.p. Kokra I (-21,57 m³/s oziroma -20,6\%), Radovna pri v.p. Podhom $\left(-13,02 \mathrm{~m}^{3} / \mathrm{s}\right.$ oziroma $\left.-17,0 \%\right)$ in Sava Bohinjka pri v. p. Sveti Janez $\left(-17,71 \mathrm{~m}^{3} / \mathrm{s}\right.$ oziroma $\left.-16,7 \%\right)$.

Manj kot $5 \%$ relativnega upada absolutnih maksimalnih letnih pretokov beležita Savinja pri v. p. Nazarje $\left(-11,76 \mathrm{~m}^{3} / \mathrm{s}\right.$ oziroma $\left.-4,7 \%\right)$ in Koritnica pri v.p. Kal-Koritnica $\left(-2,81 \mathrm{~m}^{3} / \mathrm{s}\right.$ oziroma $\left.-4,3 \%\right)$, manj kot $10 \%$ relativnega naraščanja pa Tolminka pri v.p. Tolmin $\left(2,45 \mathrm{~m}^{3} / \mathrm{s}\right.$ oziroma $\left.3,2 \%\right)$ in Sava Dolinka pri v. p. Jesenice $\left(7,05 \mathrm{~m}^{3} / \mathrm{s}\right.$ oziroma $\left.9,8 \%\right)$.

Absolutni maksimalni letni pretoki so se najbolj povečali na Tržiški Bistrici pri v.p. Preska za $17,67 \mathrm{~m}^{3} / \mathrm{s}$ oziroma $31,1 \%$ in na Soči pri v. p. Kobarid I za $85,76 \mathrm{~m}^{3} / \mathrm{s}$ oziroma $21,3 \%$.

\subsection{Podnebne spremenljivke}

V okviru podnebnih spremenljivk smo obravnavali (preglednica 3): (1) trende povprečne letne temperature zraka, (2) trende letne količine padavin, (3) trende letnega števila dni s padavinami nad 0,1 mm in (4) trende letnega števila dni s snežno odejo.

\subsubsection{Povprečna letna temperatura zraka}

Trendi povprečne letne temperature zraka v obdobju od 1961 do 2010 so na vseh osmih obravnavanih temperaturnih postajah podobni in kažejo na izrazito naraščanje (preglednica 9, slika 5). Značilna je tudi izredno visoka raven zaupanja, ki je na sedmih temperaturnih postajah 99,9\% in le na temperaturni postaji Krvavec $95 \%$.

V obravnavanem obdobju (1961-2010) je temperatura na postajah Šmartno pri Slovenj Gradcu, Mozirje, Lesce, Planina pod Golico, Rateče (slika 5), Kredarica in Bovec v povprečju letno narasla od 0,030 do $0,038^{\circ} \mathrm{C}$, kar pomeni, da so se v zadnjega pol stoletja na omenjenih postajah temperature zvišale za $1,48-1,84^{\circ} \mathrm{C}$. Absolutna temperaturna razlika v obdobju od 1961 do 2010 je največja na postajah Šmartno pri Slovenj Gradcu in Rateče, kjer je temperatura narasla za $1,8^{\circ} \mathrm{C}$.

Nekoliko manjši temperaturni dvig beleži le temperaturna postaja Krvavec, kjer se je v obravnavanem polstoletnem obdobju temperatura zvišala za $0,9^{\circ} \mathrm{C}$. 
Preglednica 7: Trendi povprečnih srednjih letnih pretokov v obdobju od 1961 do 2010.

\begin{tabular}{|c|c|c|c|c|c|c|c|c|}
\hline \multirow[t]{2}{*}{$\begin{array}{l}\text { vodomerna } \\
\text { postaja }\end{array}$} & \multirow[t]{2}{*}{ vodotok } & $\begin{array}{l}\text { Mann- } \\
\text { Kendallov } \\
\text { test }\end{array}$ & $\begin{array}{c}\text { raven } \\
\text { zaupanja }\end{array}$ & $\begin{array}{l}\text { Senov } \\
\text { naklon }\end{array}$ & $\begin{array}{c}\text { trendno } \\
\text { stanje } \\
1961\end{array}$ & $\begin{array}{l}\text { trendno } \\
\text { stanje } \\
2010\end{array}$ & $\begin{array}{c}\text { trendna } \\
\text { razlika } \\
1961- \\
2010\end{array}$ & $\begin{array}{c}\text { trendna } \\
\text { razlika } \\
1961- \\
2010\end{array}$ \\
\hline & & Z & $\%$ & Q & $\mathrm{m}^{3} / \mathrm{s}$ & $\mathrm{m}^{3} / \mathrm{s}$ & $\mathrm{m}^{3} / \mathrm{s}$ & $\%$ \\
\hline Otiški Vrh I & Meža & $-2,89$ & 99,0 & $-0,071$ & 13,92 & 10,45 & $-3,47$ & $-24,92$ \\
\hline Jesenice & Sava Dolinka & $-2,07$ & 95,0 & $-0,051$ & 11,78 & 9,29 & $-2,49$ & $-21,14$ \\
\hline Podhom & Radovna & $-1,84$ & 90,0 & $-0,028$ & 8,71 & 7,35 & $-1,36$ & $-15,58$ \\
\hline Sveti Janez & Sava Bohinjka & $-2,05$ & 95,0 & $-0,033$ & 8,90 & 7,26 & $-1,64$ & $-18,44$ \\
\hline Stara Fužina II & Mostnica & $-3,02$ & 99,0 & $-0,023$ & 3,70 & 2,68 & $-1,02$ & $-27,56$ \\
\hline Preska & Tržiška Bistrica & $-1,72$ & 90,0 & $-0,019$ & 5,28 & 4,35 & $-0,93$ & $-17,60$ \\
\hline Kokra I (slika 3) & Kokra & $-3,45$ & 99,9 & $-0,027$ & 4,94 & 3,61 & $-1,33$ & $-26,98$ \\
\hline Kamnik I & Kamniška Bistrica & $-1,78$ & 90,0 & $-0,027$ & 7,98 & 6,78 & $-1,20$ & $-15,07$ \\
\hline Nazarje & Savinja & $-1,04$ & pod 90,0 & $-0,029$ & 17,26 & 15,82 & $-1,44$ & $-8,32$ \\
\hline Kobarid I & Soča & $-1,24$ & pod 90,0 & $-0,088$ & 34,67 & 30,34 & $-4,33$ & $-12,50$ \\
\hline Kal-Koritnica & Koritnica & $-1,76$ & 90,0 & $-0,026$ & 7,74 & 6,47 & $-1,27$ & $-16,38$ \\
\hline Tolmin & Tolminka & $-0,80$ & pod 90,0 & $-0,008$ & 7,77 & 7,38 & $-0,39$ & $-5,00$ \\
\hline
\end{tabular}

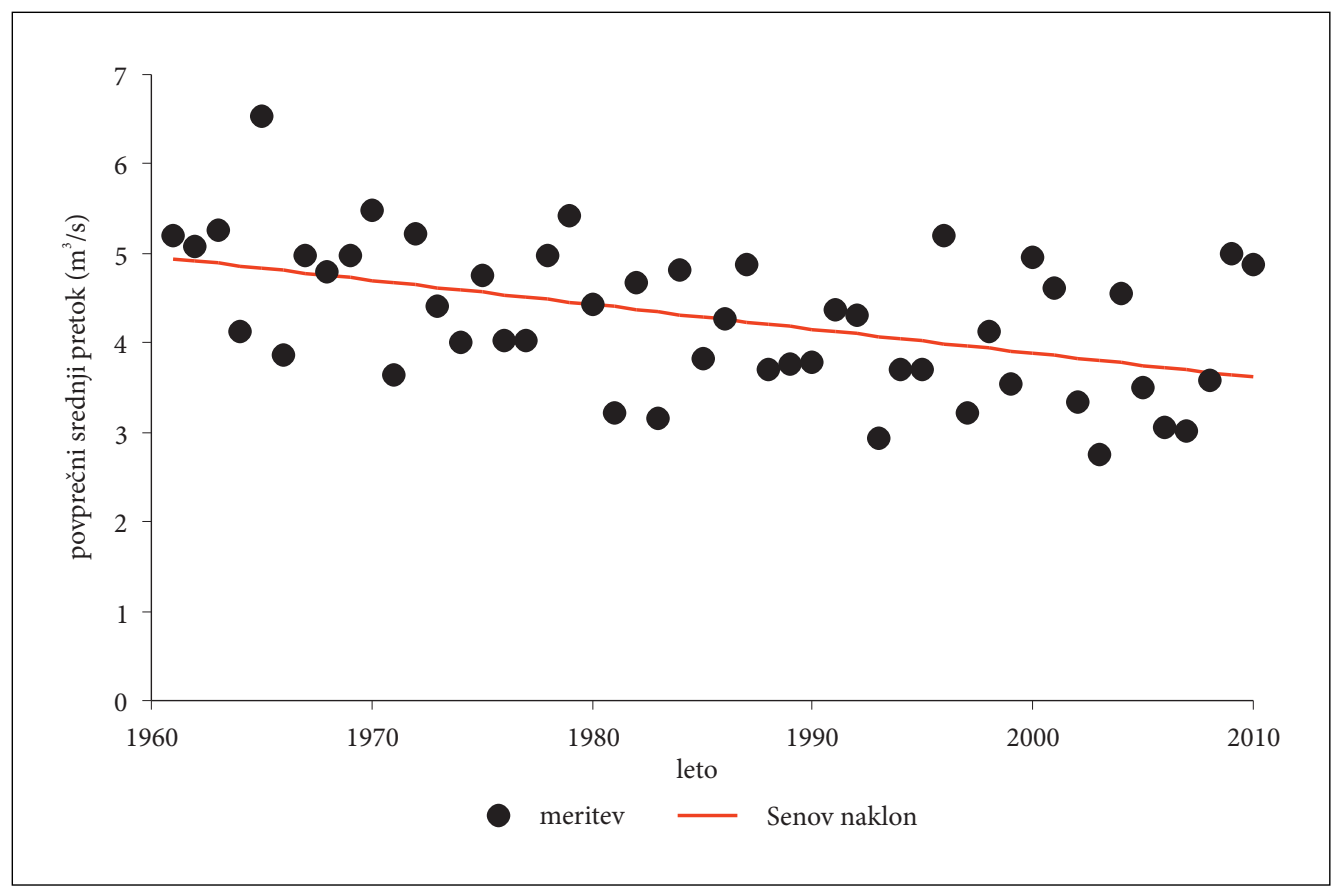

Slika 3: Trend povprečnih srednjih letnih pretokov Kokre pri vodomerni postaji Kokra I v obdobju od 1961 do 2010. 
Preglednica 8: Trendi absolutnih maksimalnih letnih pretokov v obdobju od 1961 do 2010.

\begin{tabular}{|c|c|c|c|c|c|c|c|c|}
\hline \multirow[t]{2}{*}{$\begin{array}{l}\text { vodomerna } \\
\text { postaja }\end{array}$} & \multirow[t]{2}{*}{ vodotok } & $\begin{array}{l}\text { Mann- } \\
\text { Kendallov } \\
\text { test }\end{array}$ & $\begin{array}{c}\text { raven } \\
\text { zaupanja }\end{array}$ & $\begin{array}{l}\text { Senov } \\
\text { naklon }\end{array}$ & $\begin{array}{c}\text { trendno } \\
\text { stanje } \\
1961\end{array}$ & $\begin{array}{c}\text { trendno } \\
\text { stanje } \\
2010\end{array}$ & $\begin{array}{c}\text { trendna } \\
\text { razlika } \\
1961- \\
2010\end{array}$ & $\begin{array}{c}\text { trendna } \\
\text { razlika } \\
1961- \\
2010\end{array}$ \\
\hline & & $\mathrm{Z}$ & $\%$ & Q & $\mathrm{m}^{3} / \mathrm{s}$ & $\mathrm{m}^{3} / \mathrm{s}$ & $\mathrm{m}^{3} / \mathrm{s}$ & $\%$ \\
\hline Otiški Vrh I & Meža & $-1,21$ & pod 90,0 & $-0,611$ & 144,86 & 114,92 & $-29,94$ & $-20,67$ \\
\hline Jesenice & Sava Dolinka & 0,38 & pod 90,0 & 0,144 & 71,79 & 78,84 & 7,05 & 9,81 \\
\hline Podhom & Radovna & $-1,24$ & pod 90,0 & $-0,266$ & 76,57 & 63,55 & $-13,02$ & $-17,01$ \\
\hline Sveti Janez & Sava Bohinjka & $-0,95$ & pod 90,0 & $-0,361$ & 106,03 & 88,32 & $-17,71$ & $-16,70$ \\
\hline $\begin{array}{l}\text { Stara Fužina II } \\
\text { (slika 4) }\end{array}$ & Mostnica & $-3,16$ & 99,0 & $-1,095$ & 85,88 & 36,63 & $-49,25$ & $-57,35$ \\
\hline Preska & Tržiška Bistrica & 1,26 & pod 90,0 & 0,361 & 56,80 & 74,47 & 17,67 & 31,11 \\
\hline Kokra I & Kokra & $-1,15$ & pod 90,0 & $-0,440$ & 104,64 & 83,07 & $-21,57$ & $-20,62$ \\
\hline Kamnik I & Kamniška Bistrica & $-3,22$ & 99,0 & $-1,302$ & 119,80 & 61,23 & $-58,57$ & $-48,89$ \\
\hline Nazarje & Savinja & $-0,38$ & pod 90,0 & $-0,240$ & 248,84 & 237,08 & $-11,76$ & $-4,73$ \\
\hline Kobarid I & Soča & 1,56 & pod 90,0 & 1,750 & 403,63 & 489,38 & 85,76 & 21,25 \\
\hline Kal-Koritnica & Koritnica & $-0,17$ & pod 90,0 & $-0,057$ & 65,43 & 62,62 & $-2,81$ & $-4,30$ \\
\hline Tolmin & Tolminka & 0,13 & pod 90,0 & 0,050 & 76,65 & 79,10 & 2,45 & 3,20 \\
\hline
\end{tabular}

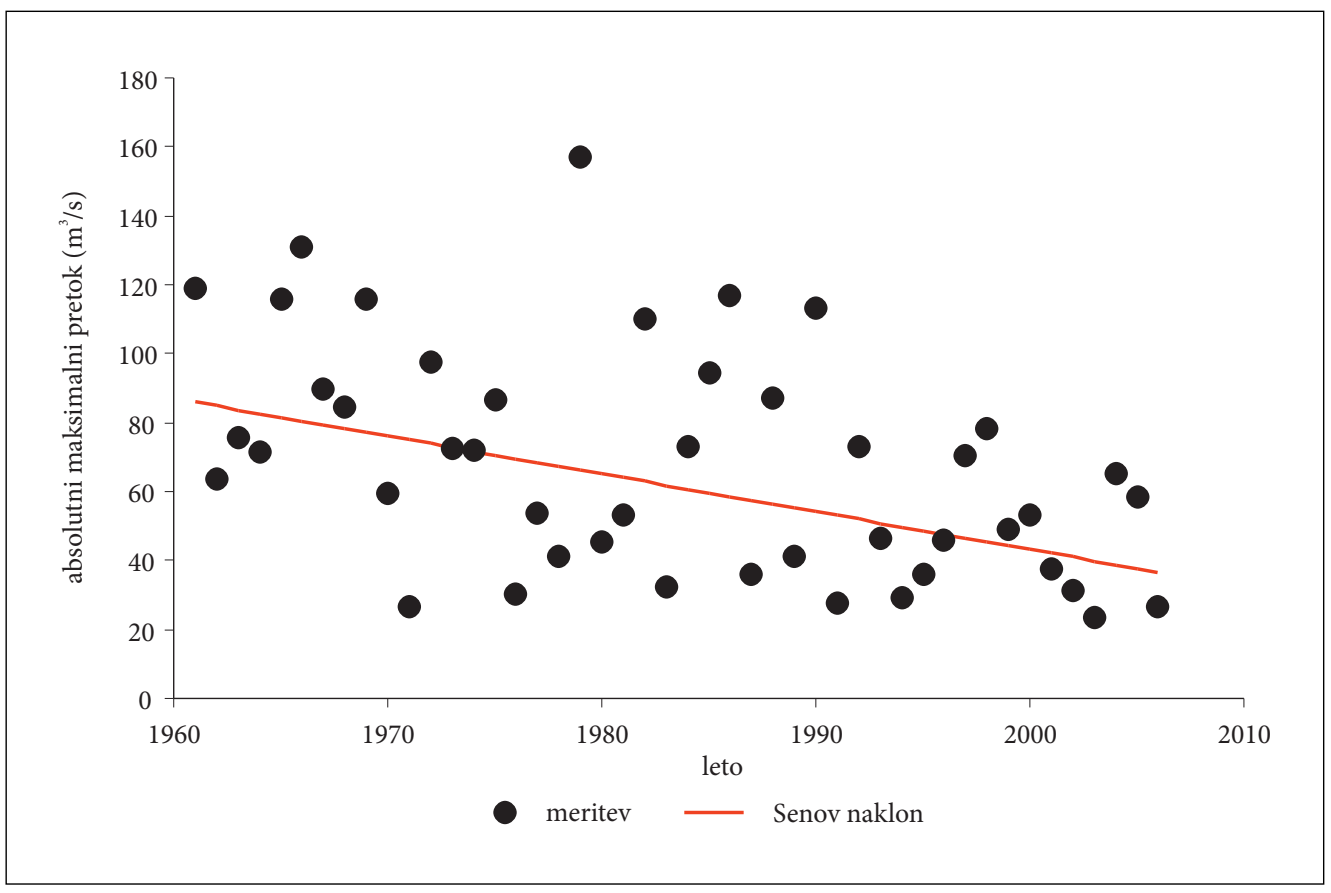

Slika 4: Trend absolutnih maksimalnih letnih pretokov Mostnice pri vodomerni postaji Stara Fužina II v obdobju od 1961 do 2010. 
Preglednica 9: Trendi povprečnih letnih temperatur v obdobju od 1961 do 2010.

\begin{tabular}{|c|c|c|c|c|c|c|c|}
\hline temperaturna postaja & $\begin{array}{l}\text { Mann- } \\
\text { Kendallov } \\
\text { test }\end{array}$ & $\begin{array}{c}\text { raven } \\
\text { zaupanja }\end{array}$ & $\begin{array}{l}\text { Senov } \\
\text { naklon }\end{array}$ & $\begin{array}{c}\text { trendno } \\
\text { stanje } \\
1961\end{array}$ & $\begin{array}{c}\text { trendno } \\
\text { stanje } \\
2010\end{array}$ & $\begin{array}{c}\text { trendna } \\
\text { razlika } \\
1961- \\
2010\end{array}$ & $\begin{array}{c}\text { trendna } \\
\text { razlika } \\
1961- \\
2010\end{array}$ \\
\hline & $\mathrm{Z}$ & $\%$ & Q & ${ }^{\circ} \mathrm{C}$ & ${ }^{\circ} \mathrm{C}$ & ${ }^{\circ} \mathrm{C}$ & $\%$ \\
\hline Šmartno pri Slovenj Gradcu & 5,26 & $99,9 \%$ & 0,038 & 7,20 & 9,04 & 1,84 & 25,56 \\
\hline Mozirje & 4,53 & $99,9 \%$ & 0,036 & 8,54 & 10,28 & 1,74 & 20,37 \\
\hline Krvavec & 2,33 & $95,0 \%$ & 0,019 & 2,79 & 3,72 & 0,93 & 33,33 \\
\hline Lesce & 4,79 & $99,9 \%$ & 0,034 & 7,53 & 9,20 & 1,67 & 22,18 \\
\hline Planina pod Golico & 4,43 & $99,9 \%$ & 0,030 & 5,65 & 7,13 & 1,48 & 26,19 \\
\hline Rateče (slika 5) & 4,98 & $99,9 \%$ & 0,036 & 5,34 & 7,10 & 1,76 & 32,96 \\
\hline Kredarica & 4,09 & $99,9 \%$ & 0,031 & $-2,17$ & $-1,17$ & 1,00 & 46,08 \\
\hline Bovec & 4,63 & $99,9 \%$ & 0,032 & 8,83 & 10,42 & 1,59 & 18,01 \\
\hline
\end{tabular}

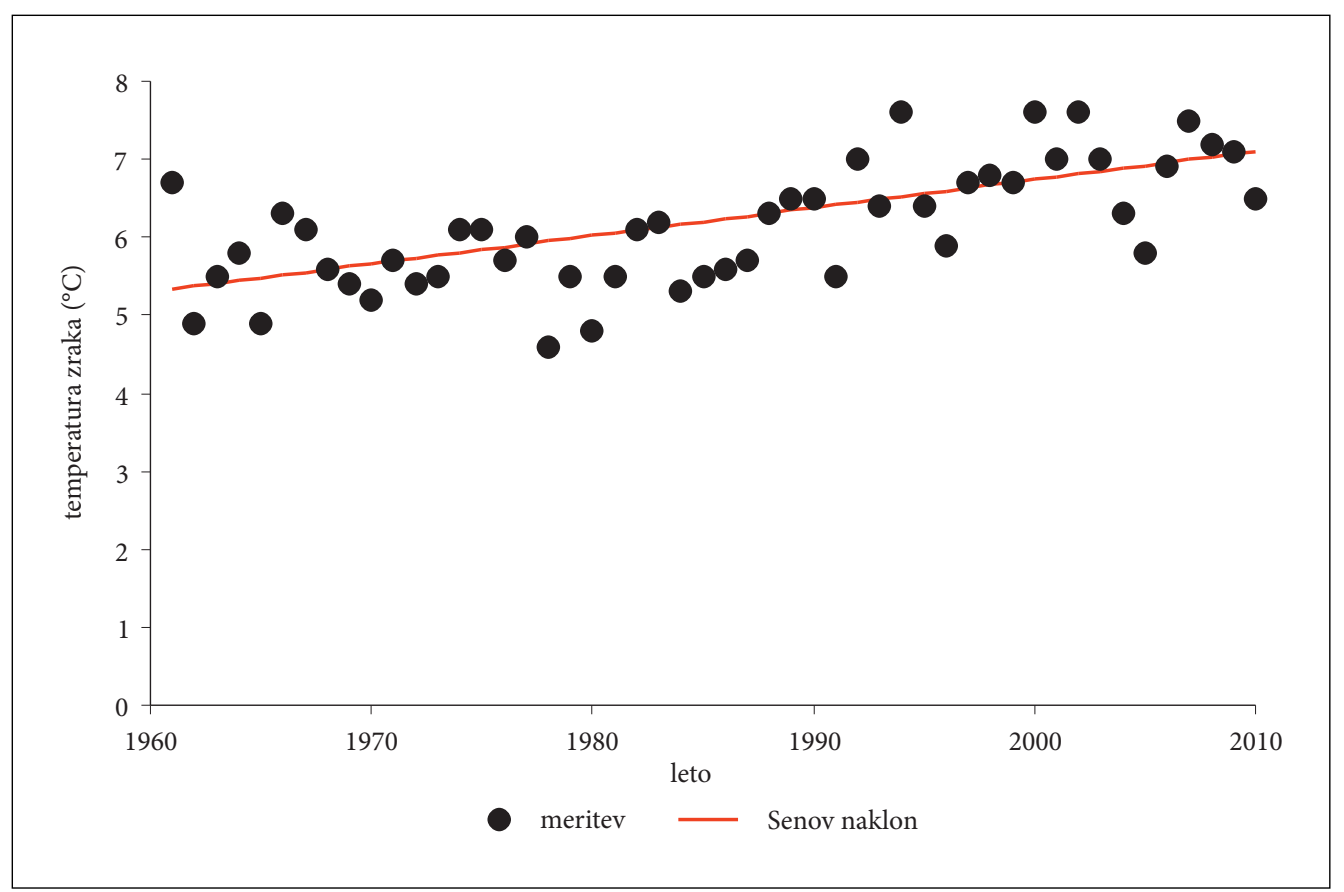

Slika 5: Trend povprečnih letnih temperatur na temperaturni postaji Rateče v obdobju od 1961 do 2010 . 


\subsubsection{Letna količina padavin}

V nasprotju s temperaturnimi trendi, ki kažejo naraščanje, so trendi letne količine padavin v obdobju od 1961 do 2010 na devetih od dvanajstih obravnavanih padavinskih postajah padajoči (preglednica 10, slika 6). Raven zaupanja je zelo skromna, saj kar na devetih postajah ne dosega niti $90 \%$. Na postajah Solčava in Rateče dosega $90 \%$, na postaji Podljubelj pa 99,9\%.

V obravnavanem obdobju (1961-2010) je količina letnih padavin na petih postajah (Solčava, Podljubelj (slika 6), Javorniški Rovt, Rateče in Bohinjska Bistrica) v povprečju letno upadla od 4 do $9 \mathrm{~mm}$, kar pomeni, da se je v zadnjega pol stoletja na omenjenih postajah količina padavin znižala za 185-465 mm oziroma za 10-23\%. Absolutna razlika količine padavin je največja na postaji Podljubelj, kjer je količina padavin upadla za 465,4 mm oziroma $23,3 \%$.

Nekoliko nižji upad letne količine padavin beleži postaja Koprivna ( $-77,9$ mm oziroma $-5,1 \%)$, na postajah Mislinja, Šmartno pri Slovenj Gradcu, Podpeca in Kamniška Bistrica pa so opazni le rahli trendni odkloni v negativni ali pozitivni smeri.

Naraščajoči trend letne količine padavin v obdobju 1961-2010 imata postaji Kredarica $(+193,12 \mathrm{~mm})$ in Soča $(+242,11 \mathrm{~mm})$. Pri obeh postajah se je v petdesetih letih količina padavin povečala za približno $10 \%$.

\subsubsection{Letno število dni s padavinami nad $0,1 \mathrm{~mm}$}

Letno število dni s padavinami nad 0,1 mm je v obdobju od 1961 do 2010 na šestih padavinskih postajah naraslo in na šestih upadlo (preglednica 11, slika 7). Raven zaupanja je močno spremenljiva: na sedmih postajah ne dosega niti $90 \%$, na postajah Šmartno pri Slovenj Gradcu in Bohinjska Bistrica dosega 95\%, na postajah Podpeca, Koprivna in Kamniška Bistrica pa je 99,0 ali 99,9\%.

Pri večini padavinskih postaj (Mislinja, Solčava, Podljubelj, Javorniški Rovt, Rateče, Kredarica in Soča) so negativna ali pozitivna trendna odstopanja manjša in ne dosegajo $10 \%$. Upadanje letnega števila dni s padavinami nad $0,1 \mathrm{~mm}$ je izrazitejše le na postajah Podpeca $(-20,6$ dni oziroma $-13,3 \%)$ in Šmartno pri Slovenj Gradcu (-17,6 dni oziroma -11,6\%), naraščanje letnega števila dni s padavinami nad 0,1 mm pa je največje na postajah Kamniška Bistrica (39,4 dni oziroma 30,7 \%), Koprivna (27,0 dni oziroma 23,4\%) in Bohinjska Bistrica (19,8 dni oziroma 16,7\%).

\subsection{4 Število dni s snežno odejo}

Število dni s snežno odejo se je v obravnavanem obdobju od 1961 do 2010 na enajstih padavinskih postajah od dvanajstih močno zmanjšalo (preglednica 12, slika 8). Edina izjema je visokogorska padavinska postaja na Kredarici, ki beleži celo rahlo naraščanje snežnih dni. Raven zaupanja je spremenljiva, a bistveno boljša od ravni zaupanja pri letnem številu dni s padavinami nad $0,1 \mathrm{~mm}$. Na treh postajah (Rateče, Bohinjska Bistrica in Kredarica) ne presega 90\%, na šestih postajah (Mislinja, Podpeca, Koprivna, Kamniška Bistrica, Podljubelj, Soča) je $95 \%$, na preostalih treh postajah (Šmartno pri Slovenj Gradcu, Solčava in Javorniški Rovt) pa vsaj $99 \%$.

V obravnavanem petdesetletnem obdobju se je število dni s snežno odejo na enajstih padavinskih postajah s padajočim trendom zmanjšalo za 23 do 50 dni oziroma za 16 do $49 \%$. Za več kot dvajset dni letno se je obdobje s snežno odejo skrajšalo na postajah Koprivna, Rateče in Bohinjska Bistrica, za več kot trideset dni na postajah Mislinja, Podpeca, Podljubelj in Soča ter za več kot štirideset dni na postajah Šmartno pri Slovenj Gradcu, Solčava, Kamniška Bistrica in Javorniški Rovt (slika 8). Absolutna negativna razlika $v$ številu dni s snežno odejo je največja na postaji Javorniški Rovt, kjer je število snežnih dni upadlo za 50, relativna negativna razlika pa je največja na postaji Kamniška Bistrica, kjer se je število dni s snežno odejo zmanjšalo za 49,4\%.

Na Kredarici, ki je edina padavinska postaja s pozitivnim trendom, se je število dni s snežno odejo v obdobju 1961-2010 povečalo za 6 oziroma za 2,2 \%. 
Preglednica 10: Trendi letnih količin padavin v obdobju od 1961 do 2010.

\begin{tabular}{|c|c|c|c|c|c|c|c|}
\hline padavinska postaja & $\begin{array}{l}\text { Mann- } \\
\text { Kendallov } \\
\text { test }\end{array}$ & $\begin{array}{c}\text { raven } \\
\text { zaupanja }\end{array}$ & $\begin{array}{l}\text { Senov } \\
\text { naklon }\end{array}$ & $\begin{array}{c}\text { trendno } \\
\text { stanje } \\
1961\end{array}$ & $\begin{array}{c}\text { trendno } \\
\text { stanje } \\
2010\end{array}$ & $\begin{array}{c}\text { trendna } \\
\text { razlika } \\
1961- \\
2010\end{array}$ & $\begin{array}{c}\text { trendna } \\
\text { razlika } \\
1961- \\
2010\end{array}$ \\
\hline & $\mathrm{Z}$ & $\%$ & Q & $\mathrm{mm}$ & $\mathrm{mm}$ & $\mathrm{mm}$ & $\%$ \\
\hline Mislinja & $-0,38$ & pod $90,0 \%$ & $-0,533$ & 1247,73 & 1221,60 & $-26,13$ & $-2,09$ \\
\hline Šmartno pri Slovenj Gradcu & 0,30 & pod $90,0 \%$ & 0,665 & 1154,44 & 1166,60 & 12,16 & 1,05 \\
\hline Podpeca & $-0,18$ & pod $90,0 \%$ & $-0,325$ & 1431,45 & 1415,53 & $-15,92$ & $-1,11$ \\
\hline Koprivna & $-0,94$ & pod $90,0 \%$ & $-1,589$ & 1536,62 & 1458,76 & $-77,86$ & $-5,07$ \\
\hline Solčava & $-1,94$ & $90,0 \%$ & $-4,007$ & 1639,02 & 1442,66 & $-196,36$ & $-11,98$ \\
\hline Kamniška Bistrica & $-0,29$ & pod $90,0 \%$ & $-1,389$ & 2134,87 & 2066,82 & $-68,05$ & $-3,19$ \\
\hline Podljubelj (slika 6) & $-3,82$ & $99,9 \%$ & $-9,499$ & 1996,67 & 1531,23 & $-465,44$ & $-23,31$ \\
\hline Javorniški Rovt & $-1,27$ & pod $90,0 \%$ & $-4,335$ & 2040,56 & 1828,15 & $-212,41$ & $-10,41$ \\
\hline Rateče & $-1,90$ & $90,0 \%$ & $-3,808$ & 1613,03 & 1426,47 & $-186,56$ & $-11,57$ \\
\hline Bohinjska Bistrica & $-1,37$ & pod $90,0 \%$ & $-5,873$ & 2201,11 & 1913,32 & $-287,79$ & $-13,07$ \\
\hline Kredarica & 1,39 & pod $90,0 \%$ & 3,941 & 1937,87 & 2130,99 & 193,12 & 9,97 \\
\hline Soča & 0,97 & pod $90,0 \%$ & 4,941 & 2299,70 & 2541,81 & 242,11 & 10,53 \\
\hline
\end{tabular}

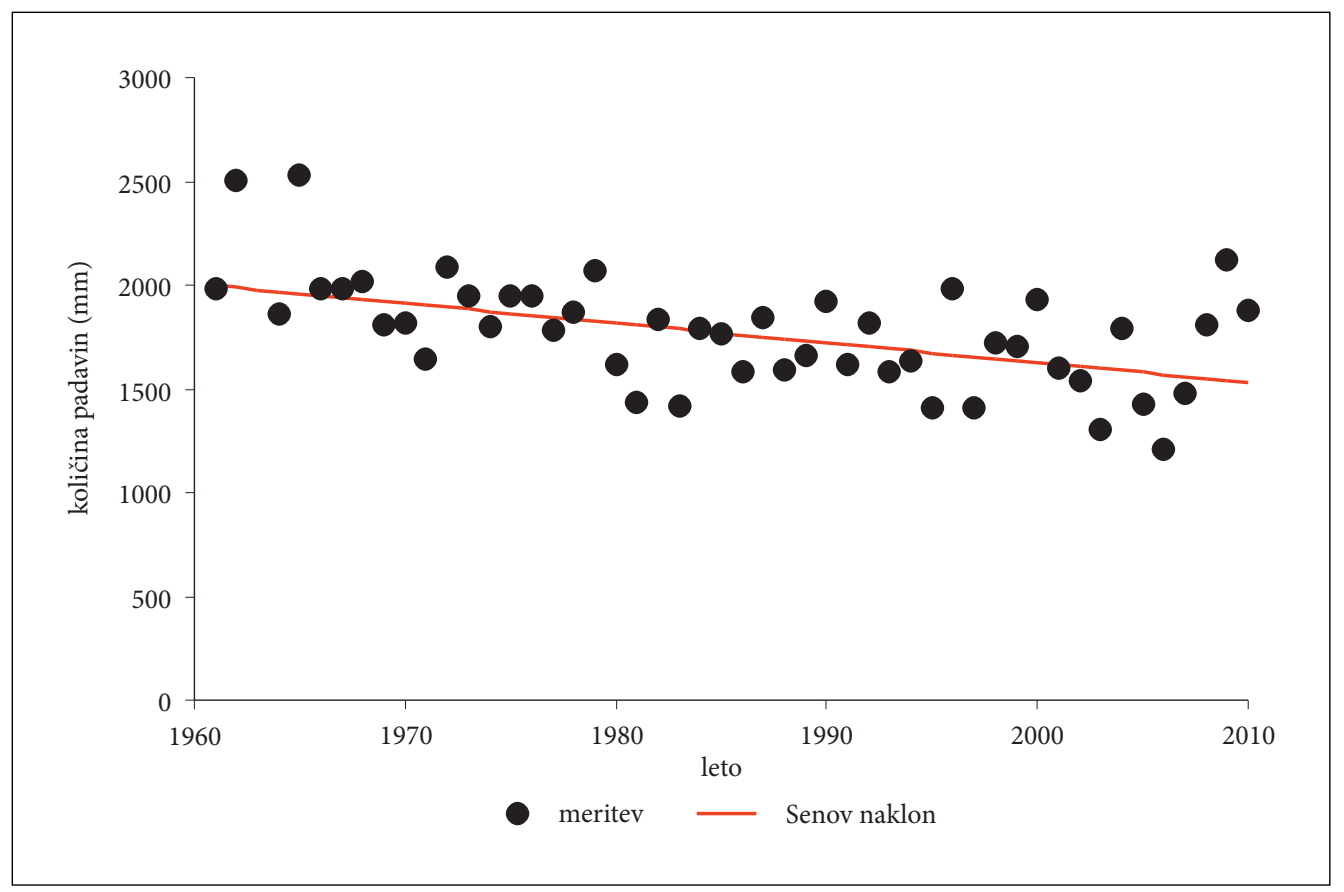

Slika 6: Trend letne količine padavin na padavinski postaji Podljubelj v obdobju od 1961 do 2010. 
Preglednica 11: Trendi števila dni s padavinami na leto v obdobju od 1961 do 2010.

\begin{tabular}{|c|c|c|c|c|c|c|c|}
\hline padavinska postaja & $\begin{array}{c}\text { Mann- } \\
\text { Kendallov } \\
\text { test }\end{array}$ & $\begin{array}{c}\text { raven } \\
\text { zaupanja }\end{array}$ & $\begin{array}{l}\text { Senov } \\
\text { naklon }\end{array}$ & $\begin{array}{c}\text { trendno } \\
\text { stanje } \\
1961\end{array}$ & $\begin{array}{c}\text { trendno } \\
\text { stanje } \\
2010\end{array}$ & $\begin{array}{c}\text { trendna } \\
\text { razlika } \\
1961- \\
2010\end{array}$ & $\begin{array}{c}\text { trendna } \\
\text { razlika } \\
1961- \\
2010\end{array}$ \\
\hline & $\mathrm{Z}$ & $\%$ & Q & $\begin{array}{c}\text { število } \\
\text { dni }\end{array}$ & $\begin{array}{c}\text { število } \\
\text { dni }\end{array}$ & $\begin{array}{c}\text { število } \\
\text { dni }\end{array}$ & $\%$ \\
\hline Mislinja & $-1,57$ & pod $90,0 \%$ & $-0,207$ & 139,22 & 129,09 & $-10,13$ & $-7,28$ \\
\hline Šmartno pri Slovenj Gradcu & $-2,29$ & $95,0 \%$ & $-0,359$ & 151,55 & 133,96 & $-17,59$ & $-11,61$ \\
\hline Podpeca & $-2,64$ & $99,0 \%$ & $-0,421$ & 155,58 & 134,95 & $-20,63$ & $-13,26$ \\
\hline Koprivna & 3,71 & $99,9 \%$ & 0,550 & 115,00 & 141,95 & 26,95 & 23,43 \\
\hline Solčava (slika 7) & $-0,90$ & pod $90,0 \%$ & $-0,111$ & 152,94 & 147,50 & $-5,44$ & $-3,56$ \\
\hline Kamniška Bistrica & 3,81 & $99,9 \%$ & 0,803 & 128,30 & 167,66 & 39,36 & 30,67 \\
\hline Podljubelj & $-0,19$ & pod $90,0 \%$ & $-0,011$ & 153,01 & 152,48 & $-0,53$ & $-0,35$ \\
\hline Javorniški Rovt & $-0,18$ & pod $90,0 \%$ & 0,000 & 160,00 & 160,00 & 0,00 & 0,00 \\
\hline Rateče & 0,53 & pod $90,0 \%$ & 0,061 & 145,67 & 148,64 & 2,97 & 2,04 \\
\hline Bohinjska Bistrica & 2,36 & $95,0 \%$ & 0,403 & 118,00 & 137,75 & 19,75 & 16,74 \\
\hline Kredarica & 0,85 & pod $90,0 \%$ & 0,179 & 168,88 & 177,63 & 8,76 & 5,18 \\
\hline Soča & $-1,47$ & pod $90,0 \%$ & $-0,167$ & 142,83 & 134,67 & $-8,16$ & $-5,72$ \\
\hline
\end{tabular}

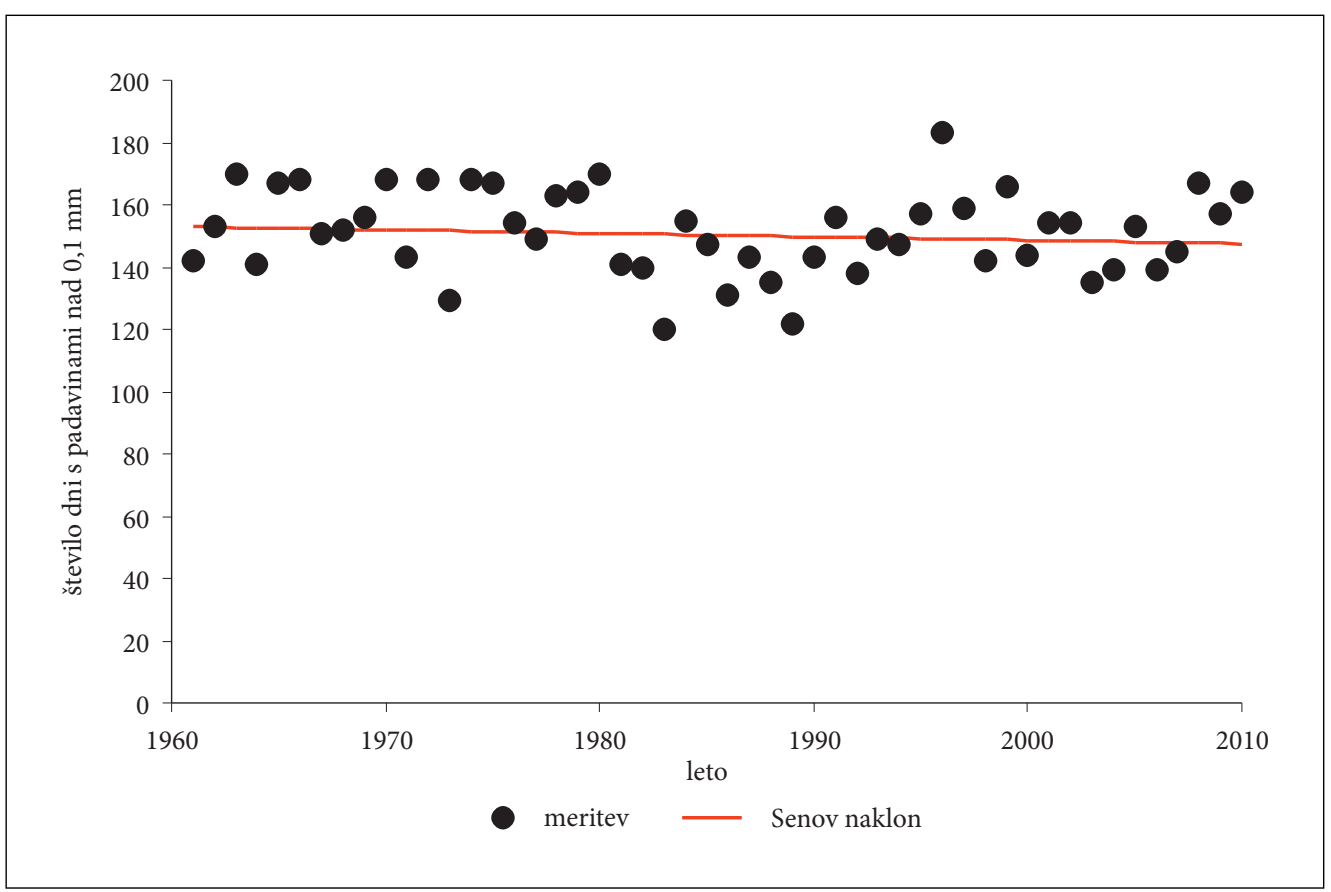

Slika 7: Trend števila dni s padavinami na leto na padavinski postaji Solčava v obdobju od 1961 do 2010 . 
Preglednica 12: Trendi števila dni s snežno odejo na leto v obdobju od 1961 do 2010.

\begin{tabular}{|c|c|c|c|c|c|c|c|}
\hline padavinska postaja & $\begin{array}{l}\text { Mann- } \\
\text { Kendallov } \\
\text { test }\end{array}$ & $\begin{array}{c}\text { raven } \\
\text { zaupanja }\end{array}$ & $\begin{array}{l}\text { Senov } \\
\text { naklon }\end{array}$ & $\begin{array}{c}\text { trendno } \\
\text { stanje } \\
1961\end{array}$ & $\begin{array}{c}\text { trendno } \\
\text { stanje } \\
2010\end{array}$ & $\begin{array}{c}\text { trendna } \\
\text { razlika } \\
1961- \\
2010\end{array}$ & $\begin{array}{c}\text { trendna } \\
\text { razlika } \\
1961- \\
2010\end{array}$ \\
\hline & $\mathrm{Z}$ & $\%$ & Q & $\begin{array}{c}\text { število } \\
\text { dni }\end{array}$ & $\begin{array}{c}\text { število } \\
\text { dni }\end{array}$ & $\begin{array}{c}\text { število } \\
\text { dni }\end{array}$ & $\%$ \\
\hline Mislinja & $-2,54$ & $95,0 \%$ & $-0,698$ & 109,70 & 75,51 & $-34,19$ & $-31,17$ \\
\hline Šmartno pri Slovenj Gradcu & $-3,23$ & $99,0 \%$ & $-0,919$ & 98,31 & 53,28 & $-45,03$ & $-45,80$ \\
\hline Podpeca & $-2,49$ & $95,0 \%$ & $-0,640$ & 121,88 & 90,52 & $-31,36$ & $-25,73$ \\
\hline Koprivna & $-2,32$ & $95,0 \%$ & $-0,583$ & 140,67 & 112,08 & $-28,59$ & $-20,32$ \\
\hline Solčava & $-2,80$ & $99,0 \%$ & $-0,840$ & 102,76 & 61,60 & $-41,16$ & $-40,05$ \\
\hline Kamniška Bistrica & $-2,53$ & $95,0 \%$ & $-0,842$ & 83,50 & 42,24 & $-41,26$ & $-49,41$ \\
\hline Podljubelj & $-2,04$ & $95,0 \%$ & $-0,709$ & 96,49 & 63,00 & $-33,49$ & $-34,71$ \\
\hline Javorniški Rovt (slika 8) & $-3,72$ & $99,9 \%$ & $-1,025$ & 137,01 & 86,79 & $-50,22$ & $-36,66$ \\
\hline Rateče & $-1,92$ & $90,0 \%$ & $-0,474$ & 143,05 & 119,84 & $-23,21$ & $-16,23$ \\
\hline Bohinjska Bistrica & $-1,52$ & pod $90,0 \%$ & $-0,603$ & 99,31 & 69,78 & $-29,53$ & $-29,74$ \\
\hline Kredarica & 0,66 & pod $90,0 \%$ & 0,118 & 261,85 & 267,62 & 5,77 & 2,20 \\
\hline Soča & $-2,26$ & $95,0 \%$ & $-0,677$ & 91,19 & 58,00 & $-33,19$ & $-36,40$ \\
\hline
\end{tabular}

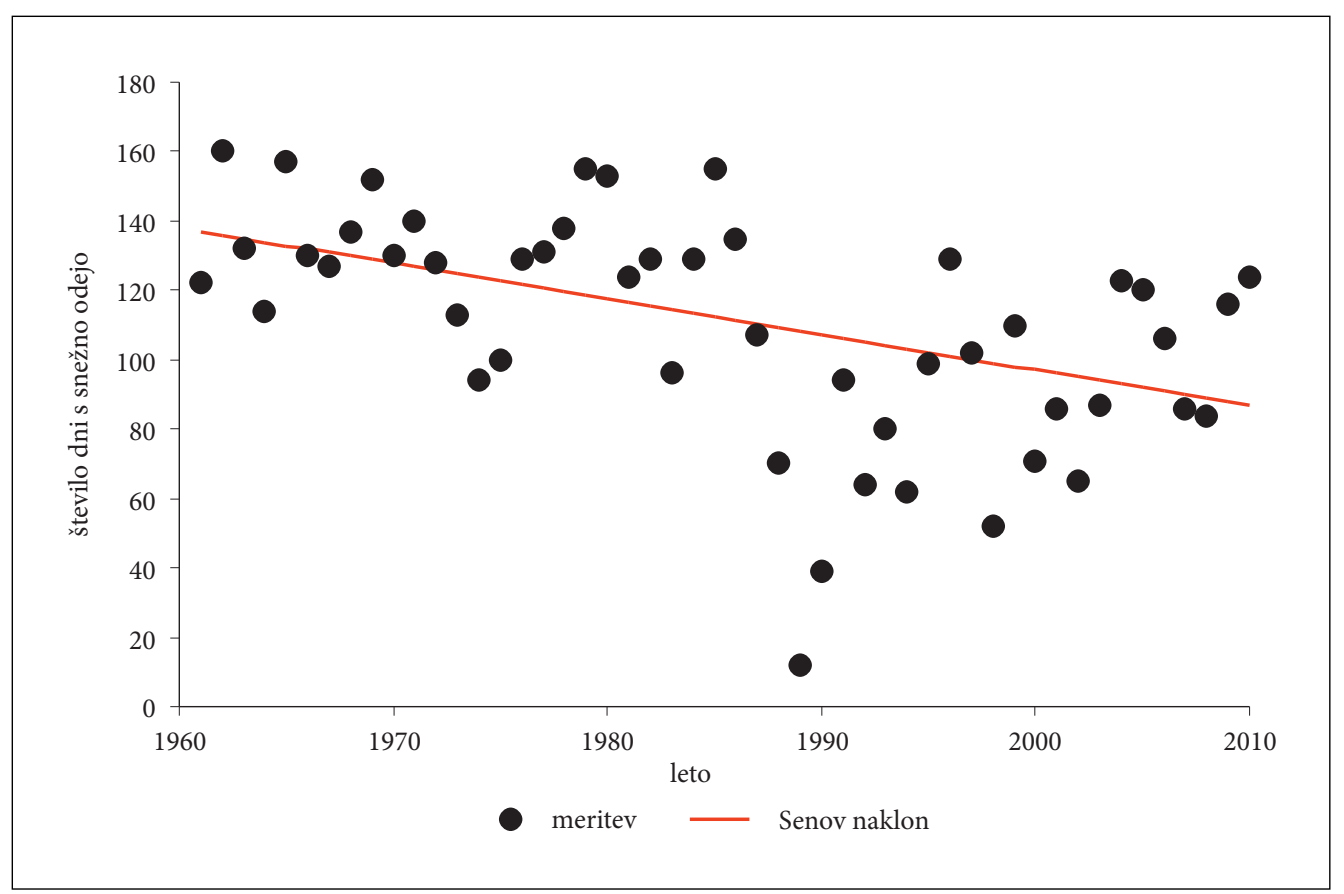

Slika 8: Trend števila dni s snežno odejo na leto na padavinski postaji Javorniški Rovt v obdobju od 1961 do 2010. 


\subsection{Pretočni režimi}

Temperaturne in padavinske spremembe ne vplivajo samo na vodne količine povprečnih ter absolutnih minimalnih in maksimalnih pretokov temveč pomembno vplivajo tudi na spreminjanje pretočnih režimov (Hrvatin 1998; Frantar 2005; Frantar in Hrvatin 2005). Med obravnavanimi podnebnimi kazalniki se zdijo še posebej pomembne spremembe v številu dni s snežno odejo, ki močno prizadenejo vse pretočne režime $\mathrm{z}$ izrazito snežno komponento.

Ob razvrščanju pretočnih režimov na temelju podatkovnega niza od 1961 do 1990 (Hrvatin 1998, 86) so se Sava Dolinka, Radovna, Sava Bohinjka, Mostnica, Kamniška Bistrica, Soča (pri v. p. Kobarid), Koritnica in Tolminka uvrstile med reke z alpskim visokogorskim snežno-dežnim režimom, Meža, Tržiška Bistrica, Kokra in Savinja (pri v.p. Nazarje) pa med reke z alpskim sredogorskim snežno-dežnim režimom. Pri rekah z alpskim visokogorskim snežno-dežnim režimom je glavni pretočni višek nastopil maja ali junija, drugotni višek pa novembra. Glavni nižek je bil februarja ali januarja, drugotni pa avgusta. Reke z alpskim sredogorskim snežno-dežnim režimom so imele glavni pretočni višek aprila ali izjemoma maja in drugotnega v novembru. Zimski (februarski ali januarski) in poletni (avgustovski) nižek sta bila izenačena.

Primerjava pretočnih režimov na temelju podatkovnega niza od 1961 do 1990 s pretočnimi režimi na temelju podatkovnega niza od 1981 do 2010 je pokazala predvsem naslednje razlike (preglednica 13, slika 9):

- spomladanski (glavni) in jesenski (drugotni) pretočni višek sta skoraj izenačena,

- zimski (glavni) in poletni (drugotni) pretočni nižek postajata bolj izrazita,

- decembrske vode močno naraščajo in so blizu letnega povprečja ali ga celo presegajo ter kažejo na "zamujanje« zime.

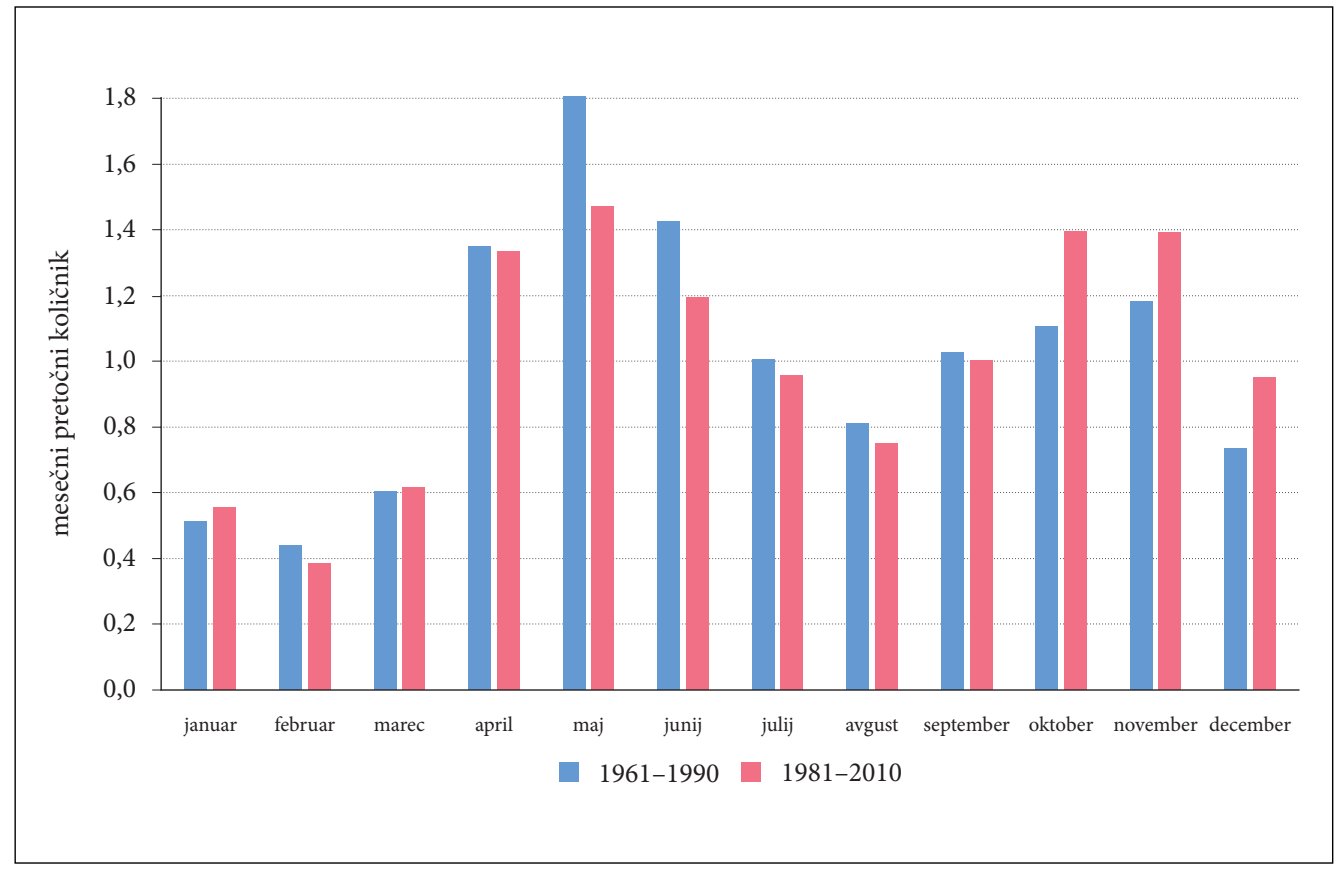

Slika 9: Sprememba pretočnega režima Radovne na vodomerni postaji Podhom med obdobjema 1961-1990 in 1981-2010. 


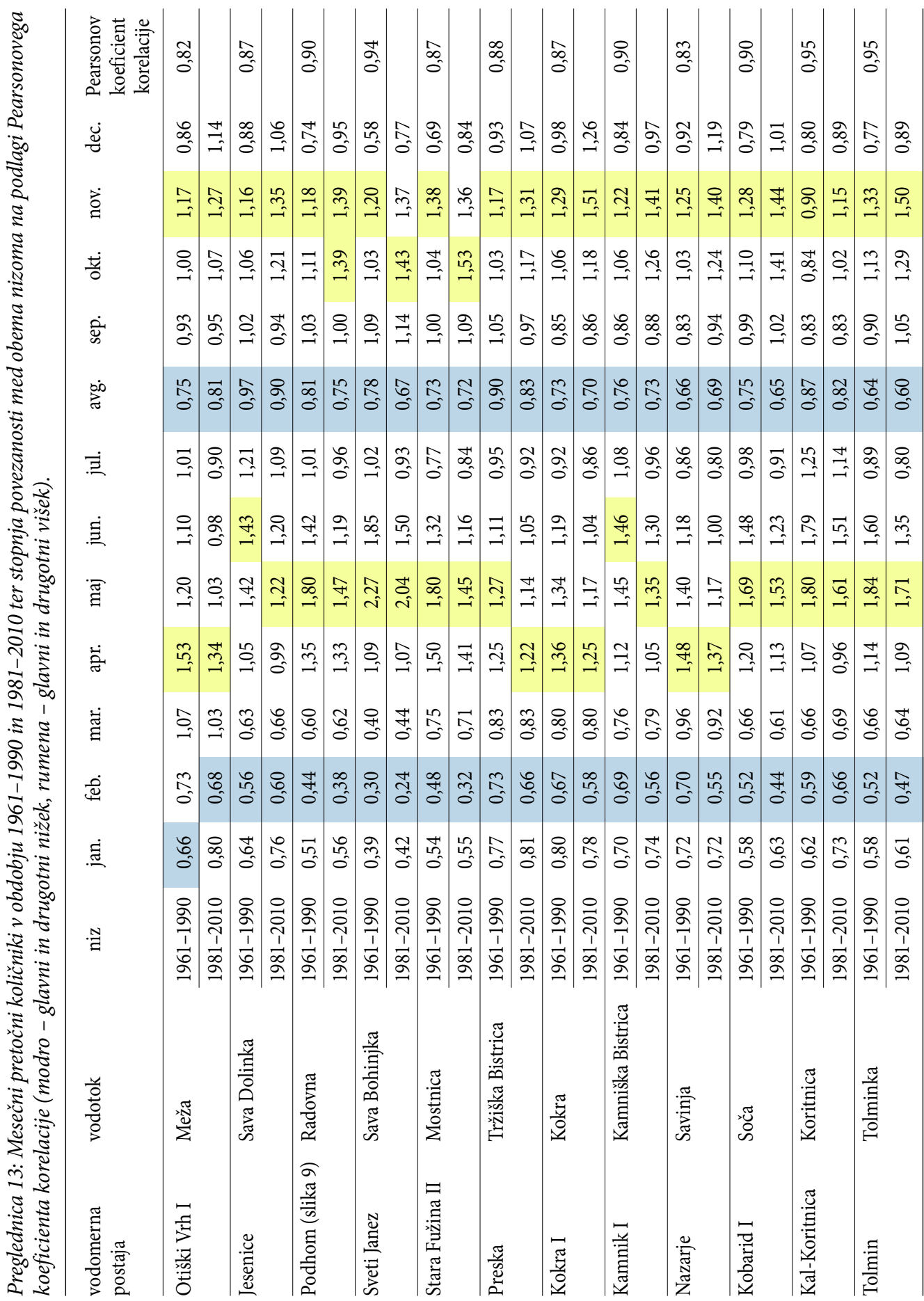


Intenziteto sprememb mesečnih pretočnih količnikov posameznih rek med tridesetletnima obdobjema 1961-1990 in 1981-2010 smo ugotavljali s Pearsonovim koeficientom korelacije (preglednica 13). Rezultati kažejo, da je stopnja povezanosti med obema nizoma pri Meži, Savi Dolinki, Mostnici, Tržiški Bistrici, Kokri in Savinji visoka (koeficienti od 0,82 do 0,88), pri Radovni, Savi Bohinjki, Kamniški Bistrici, Soči, Koritnici in Tolminki pa zelo visoka (koeficienti od 0,90 do 0,95 ). Najnižje vrednosti Pearsonovih koeficientov korelacije smo ugotovili pri mesečnih pretočnih količnikih Meže $(0,82)$ in Savinje $(0,83)$, najvišje pa pri Koritnici in Tolminki $(0,95)$. Ob tem je treba pripomniti, da smo petdesetletno obdobje od 1961 do 2010 razdelili na dva tridesetletna hidrološka niza (1961-1990 in 1981-2010), kar pomeni, da je tretjina podatkov (za obdobje 1981-1990) pri obeh nizih popolnoma enaka.

\subsection{Raba tal}

Med dejavnike, ki jih je treba upoštevati pri hidrološki analizi izbrane pokrajine, spadajo poleg kritične ocene podatkov, še analize sprememb količin podzemne vode, podnebnih dejavnikov, porabe vode in rabe tal (Bat in Uhan 2004, 126). V zadnjih desetletjih je ravno raba tal podvržena hitrim in obsežnim spremembam. Petek $(2005,113)$ je med preučevanjem sprememb rabe tal v slovenskem alpskem svetu ugotovil, da so bile razmere leta 1953 podobne tistim iz začetka 20. stoletja, leta 1979 pa je zemljiški kataster zaznal že močno upadanje deleža njiv, travnikov in pašnikov, kar je bila posledica industrializacije in prehoda kmetij na proizvodnjo za trg (Petek 2005, 116). Do leta 1999 se je delež njiv, travnikov in pašnikov dodatno zmanjšal, vendar manj kot v predhodnem primerjalnem obdobju (Petek 2005, 119).

Petek $(2005,119)$ je ob tem opozoril, da je dejansko zmanjšanje površin kmetijskih zemljišč težko določiti zaradi dejstva, da se podatki v zemljiškem katastru ne obnavljajo redno in so v vse večjem zaostanku. Upoštevani podatki za leto 2017 zato niso več iz zemljiškega katastra, temveč so pridobljeni iz evidence dejanske rabe kmetijskih in gozdnih zemljišč na GIS portalu Ministrstva za kmetijstvo, gozdarstvo in prehrano (Grafični ... 2017), ki se redno obnavlja vsake tri mesece in na ta način redno spremlja spremembe v rabi tal. Velika razlika v deležu gozda med letoma 1999 in 2017 torej ni samo posledica sprememb v rabi tal, temveč je hkrati tudi posledica spremenjene oziroma izboljšane metodologije zajemanja podatkov.

Med množico sprememb različnih zemljiških kategorij posebej izstopajo spremembe deleža gozdnih zemljišč (preglednica 14). Kmalu po drugi svetovni vojni je gozd pokrival le slabo polovico površja slovenskega alpskega sveta, danes pa njegov delež že presega sedem desetin površja. Najbolj gozdnate so Vzhodne Karavanke, kjer gozd prekriva skoraj devet desetin vseh zemljišč. Več kot tri četrtine površja zavzema gozd v Savinjskih Alpah, več kot sedem desetin površja pa v Zahodnih Karavankah in Savskih Julijskih Alpah. Še najmanj gozda je v Soških Julijskih Alpah, kjer bo kmalu dosegel mejo dveh tretjin.

Preglednica 14: Spreminjanje deleža gozda po alpskih enotah Slovenije v obdobju od 1953 do 2017 ( ${ }^{\star}$ po zemljiškem katastru, ${ }^{* *}$ po evidenci dejanske rabe kmetijskih in gozdnih zemljišč; Grafični ... 2017).

\begin{tabular}{lcccc}
\hline del alpskega sveta & $1953^{*}$ & $1979^{*}$ & $1999^{*}$ & $2017^{* *}$ \\
\hline Soške Julijske Alpe & $\%$ & $\%$ & $\%$ & $\%$ \\
Savske Julijske Alpe & 28,7 & 34,4 & 39,8 & 65,2 \\
Zahodne Karavanke & 51,1 & 54,5 & 57,0 & 71,6 \\
Vzhodne Karavanke & 54,4 & 58,8 & 60,7 & 73,0 \\
Kamniške Alpe & 52,7 & 76,4 & 77,3 & 88,1 \\
Savinjske Alpe & 57,0 & 60,6 & 61,0 & 68,3 \\
alpski svet skupaj & 48,9 & 64,3 & 64,4 & 77,9 \\
\hline
\end{tabular}


Delež gozdnih zemljišč je zelo pomemben tudi s hidrološkega vidika, saj lahko drevesa s prestrezanjem padavin in transpiracijo bistveno zmanjšajo količino vode, ki doseže podtalnico ali površinske vodotoke. Prestrezanje, oziroma zadrževanje in izhlapevanje vode iz drevesnih krošenj, lahko zadrži od 6 do 93 \% padavin (Smolej 1988, 194), v vegetacijski dobi pa je v gozdnatih pokrajinah treba upoštevati vpliv transpiracije zaradi katere se letne izgube padavinske vode gibljejo od 200 do $300 \mathrm{~mm}$ (Smolej 1988, 198).

\section{Sklep}

Poglavitna spoznanja o spremembah izbranih hidroloških in podnebnih spremenljivk v obdobju med letoma 1961 in 2010 približno sovpadajo s predstavljenimi trendi drugih avtorjev in jih lahko strnemo takole:

- Trendi absolutnih minimalnih letnih pretokov v obdobju od 1961 do 2010 so pri desetih alpskih rekah od dvanajstih izrazito padajoči. Trendna razlika je skromna le na Savi Bohinjki in Soči, na vseh preostalih vodotokih pa presega vsaj $15 \%$. Absolutni minimalni pretoki so se zmanjšali za 0,09 do $1,85 \mathrm{~m}^{3} / \mathrm{s}$, v relativnem smislu pa beleži večina vodotokov upad od 15 do $39 \%$.

- Trendi povprečnih srednjih letnih pretokov v obdobju od 1961 do 2010 so na vseh dvanajstih alpskih rekah padajoči. Pretoki so se zmanjšali za 0,39 do $4,33 \mathrm{~m}^{3} / \mathrm{s}$, v relativnem smislu pa beleži večina vodotokov upad od 15 do $25 \%$, manj kot $10 \%$ le Tolminka in Savinja.

- Trendi absolutnih maksimalnih letnih pretokov v obdobju od 1961 do 2010 so na osmih alpskih rekah padajoči, na štirih rekah pa je trend naraščajoč. Med rekami z negativnim trendom so se pretoki najbolj zmanjšali na Mostnici (-57\%) in Kamniški Bistrici ( $-49 \%)$, med rekami s pozitivnim trendom pa so se pretoki najbolj povečali na Tržiški Bistrici (31\%) in Soči (21\%).

- Povprečna letna temperatura zraka je v obdobju od 1961 do 2010 na sedmih temperaturnih postajah letno narasla od 0,030 do $0,038^{\circ} \mathrm{C}$, kar pomeni, da so se v petdesetih letih na teh postajah temperature zvišale za $1,48-1,84^{\circ} \mathrm{C}$. Nekoliko manjši temperaturni dvig beleži le temperaturna postaja Krvavec, kjer se je temperatura zvišala za $0,93^{\circ} \mathrm{C}$.

- Letna količina padavin se je v obdobju od 1961 do 2010 na devetih od dvanajstih alpskih padavinskih postaj zmanjšala. Na petih postajah $\mathrm{z}$ največjim upadanjem se je količina padavin $\mathrm{v}$ povprečju letno zmanjšala od 4 do $9 \mathrm{~mm}$, kar pomeni, da se je $\mathrm{v}$ zadnjega pol stoletja na omenjenih postajah količina padavin znižala za 185-465 mm oziroma za 10-23\%. Naraščajoči trend letne količine padavin imata postaji Kredarica in Soča. Pri obeh se je v petdesetih letih količina padavin povečala za približno $10 \%$.

- Letno število dni s padavinami nad 0,1 mm je v obdobju od 1961 do 2010 na šestih padavinskih postaja naraslo in na šestih upadlo. Pri večini padavinskih postaj so negativna ali pozitivna trendna odstopanja manjša in ne dosegajo $10 \%$. Upadanje je izrazitejše le na postajah Podpeca $(-13,3 \%)$ in Šmartno pri Slovenj Gradcu (-11,6 \%), naraščanje pa je največje na postajah Kamniška Bistrica (30,7 \%), Koprivna $(23,4 \%)$ in Bohinjska Bistrica (16,7\%).

- Število dni s snežno odejo se je v obdobju od 1961 do 2010 na enajstih alpskih padavinskih postajah od dvanajstih zmanjšalo za 23-50 dni oziroma za 16-49\%. Edina izjema je visokogorska padavinska postaja na Kredarici, kjer se je število dni s snežno odejo povečalo za 6 oziroma za 2,2 \%.

- Primerjava pretočnih režimov na temelju podatkovnega niza od 1981 do 2010 s pretočnimi režimi na temelju podatkovnega niza od 1961 do 1990 kaže, da postajata spomladanski (glavni) in jesenski (drugotni) pretočni višek vse bolj izenačena, da postajata zimski (glavni) in poletni (drugotni) pretočni nižek vse bolj izrazita ter da posebej močno naraščajo decembrske vode, kar kaže na »zamujanje« zime.

- Več kot sedem desetin površja slovenskega alpskega sveta prekriva gozd, ki s prestrezanjem padavin in transpiracijo bistveno zmanjšuje količino vode, ki doseže podtalnico in površinske vodotoke. 
Zahvala: Raziskava je bila izvedena v okviru temeljnega raziskovalnega projekta »Prožnost alpskih pokrajin $z$ vidika naravnih nesreč» (J6-6853) in raziskovalnega programa »Geografija Slovenije» (P6-0101), ki ju financira Javna agencija za raziskovalno dejavnost Republike Slovenije.

\section{Viri in literatura}

Arhiv hidroloških podatkov. Agencija Republike Slovenije za okolje. Ljubljana, 2017. Medmrežje: http://vode.arso.gov.si/hidarhiv/; http://www.arso.gov.si/vode/podatki/arhiv/hidroloski_arhiv.html (21.4.2017).

Arhiv meteoroloških podatkov. Agencija Republike Slovenije za okolje. Ljubljana, 2017. Medmrežje: http://meteo.arso.gov.si/ (21.4.2017).

Arnell, N. W., Gosling, S. N. 2013: The impacts of climate change on river flow regimes at the global scale. Journal of Hydrology 486. DOI: https://doi.org/10.1016/j.jhydrol.2013.02.010

Bat, M., Uhan, J. 2004: Vode. Narava Slovenije. Ljubljana.

Bezak, N., Brilly, M., Šraj, M. 2016: Flood frequency analyses, statistical trends and seasonality analyses of discharge data: a case study of the Litija station on the Sava River. Journal of Flood Risk Management 9-2. DOI: https://doi.org/10.1111/jfr3.12118

Birsan, M.-V., Molnar, P., Burlando, P., Pfaundler, M. 2005: Streamflow trends in Switzerland. Journal of Hydrology 314. DOI: https://doi.org/10.1016/j.jhydrol.2005.06.008

Bocchiola, D. 2014: Long term (1921-2011) hydrological regime of Alpine catchments in Northern Italy. Advances in Water Resources 70. DOI: https://doi.org/10.1016/j.advwatres.2014.04.017

Bormann, H. 2010: Runoff regime changes in German rivers due to climate change. Erdkunde 64-3. DOI: https://doi.org/10.3112/erdkunde.2010.03.04

ClimateChangePost: Slovenia. Medmrežje: https://www.climatechangepost.com/slovenia/climate-change/ (8. 8.2017).

Čanjevec, I., Orešić, D. 2018: Changes in discharge regimes of rivers in Croatia. Acta geographica Slovenica 58-2. DOI: https://doi.org/10.3986/AGS.2004

De Luis, M., Čufar, K., Saz, M. A., Longares, L. A., Ceglar, A., Kajfež-Bogataj, L. 2014: Trends in seasonal precipitation and temperature in Slovenia during 1951-2007. Regional Environmental Change 14-5. DOI: https://doi.org/10.1007/s10113-012-0365-7

Dolinar, M. (ur.) 2010: Spremenljivost podnebja v Sloveniji. Ljubljana.

Dolinar, M., Vertačnik, G. 2010: Spremenljivost temperaturnih in padavinskih razmer v Sloveniji. Okolje se spreminja: Podnebna spremenljivost Slovenije in njen vpliv na vodno okolje. Ljubljana.

Frantar, P. 2005: Pretočni režimi slovenskih rek in njihova spremenljivost. Ujma 19.

Frantar, P., Hrvatin, M. 2005: Pretočni režimi v Sloveniji med letoma 1971 in 2000. Geografski vestnik 77-2. Frantar, P., Kobold, M., Ulaga, F. 2008: Trend pretokov. Vodna bilanca Slovenije 1971-2000. Ljubljana.

Gabrovec, M., Hrvatin, M., Komac, B., Ortar, J., Pavšek, M., Topole, M., Triglav Čekada, M., Zorn, M. 2014: Triglavski ledenik. Geografija Slovenije 30. Ljubljana.

Goler, R. A., Frey, S., Formayer, H., Holzmann, H. 2016: Influence of climate change on river discharge in Austria. Meteorologische Zeitschrift 25-5. DOI: https://doi.org/10.1127/metz/2016/0562

Grafični podatki RABA za celo Slovenijo. Ministrstvo za kmetijstvo, gozdarstvo in prehrano. Ljubljana, 2017. Medmrežje: http://rkg.gov.si/GERK/ (21.2.2017).

Hrvatin, M. 1998: Pretočni režimi v Sloveniji. Geografski zbornik 38.

Hrvatin, M., Zorn, M. 2017: Trendi temperatur in padavin ter trendi pretokov rek v Idrijskem hribovju. Geografski vestnik 89-1. DOI: https://doi.org/10.3986/GV89101

Janža, M. 2013: Impact assessment of projected climate change on the hydrological regime in the SE Alps, Upper Soča River basin, Slovenia. Natural Hazards 67-3. DOI: https://doi.org/10.1007/ s11069-011-9892-7 
Kajfež-Bogataj, L. 2006: Podnebne spremembe in nacionalna varnost. Ujma 20.

Kajfež-Bogataj, L., Pogačar, T., Ceglar, A., Črepinšek, Z. 2010: Spremembe agro-klimatskih spremenljivk v Sloveniji v zadnjih desetletjih. Acta agriculturae Slovenica 95-1.

Kobold, M. 2007: Vpliv podnebnih sprememb na pretoke slovenskih rek. 18. Mišičev vodarski dan. Maribor.

Kobold, M., Dolinar, M., Frantar, P. 2012: Spremembe vodnega režima zaradi podnebnih sprememb in drugih antropogenih vplivov. 1. kongres o vodah Slovenije. Ljubljana.

Kovačič, G. 2016: Trendi pretokov rek jadranskega povodja v Sloveniji brez Posočja. Geografski vestnik 88-2. DOI: https://doi.org/10.3986/GV88201

Kovačič, G., Kolega, N., Brečko Grubar, V. 2016: Vpliv podnebnih sprememb na količine vode in poplave morja v slovenski Istri. Geografski vestnik 88-1. DOI: https://doi.org/10.3986/GV88101

Kraner Šumenjak, T., Šuštar, V. 2011: Parametrični in neparametrični pristopi za odkrivanje trenda $\mathrm{v}$ časovnih vrstah. Acta agriculturae Slovenica 97-3.

Makor, S. 2016: Trendi spreminjanja pretokov rek v Slovenij. Diplomsko delo, Fakulteta za gradbeništvo in geodezijo Univerze v Ljubljani. Ljubljana.

Medmrežje 1: http://en.ilmatieteenlaitos.fi/makesens (24. 7. 2017).

Milošević, D. D., Savić, S. M., Stankov, U., Žiberna, I., Pantelić, M. M., Dolinaj, D., Leščešen, I. 2017: Maximum temperatures over Slovenia and their relationship with atmospheric circulation patterns. Geografie 122-1.

Milošević, D. D., Savić, S. M., Žiberna, I. 2013: Analysis of the climate change in Slovenia: fluctuations of meteorological parameters for the period 1961-2011 (Part I). Glasnik Srpskog geografskog društva 93-1. DOI: https://doi.org/10.2298/GSGD1301001M

Ogrin, D. 1996: Podnebni tipi v Sloveniji. Geografski vestnik 68.

Ogrin, D. 2003: Spreminjanje temperature zraka in padavin po letnih časih v Ljubljani in Trstu v obdobju 1851-2002. Dela 20.

Ogrin, D. 2014: Tendence spreminjanja podnebja po 2. svetovni vojni na jugovzhodu krasa. Dela 41. DOI: https://doi.org/10.4312/dela.41.4.81-100

Perko, D. 1998: The regionalization of Slovenia. Geografski zbornik 38.

Perko, D., Kladnik, D. 1998: Nova regionalizacija Slovenije. Slovenija pokrajine in ljudje. Ljubljana.

Petek, F. 2005: Spremembe rabe tal v slovenskem alpskem svetu. Geografija Slovenije 11. Ljubljana.

Salmi, T., Määttä, A., Anttila, P., Ruoho-Airola, T., Amnell, T. 2002: Detecting trends of annual values of atmospheric pollutants by the Mann-Kendall test and Sen's slope estimates - the Excel template application MAKESENS. Publications on Air Quality No. 31. Helsinki.

Smolej, I. 1988: Gozdna hidrologija. Ljubljana.

Sušnik, A. (ur.) 2004: Spremembe podnebja in kmetijstvo v Sloveniji. Ljubljana.

Šraj, M., Menih, M., Bezjak, N. 2016: Climate variability impact assessment on the flood risk in Slovenia. Physical Geography 37-1. DOI: https://doi.org/10.1080/02723646.2016.1155389

Trenberth, K. E., Jones, P. D., Ambenje, P., Bojariu, R., Easterling, D., Klein Tank, A. Parker, D. Rahimzadeh, F., Renwick, J. A., Rusticucci, M., Soden, B., Zhai, P. 2007: Observations: Surface and atmospheric climate change. Climate Change 2007: The Physical Science Basis. Contribution of Working Group I to the Fourth Assessment Report of the Intergovernmental Panel on Climate Change. Cambridge. Medmrežje: https://www.ipcc.ch/publications_and_data/ar4/wg1/en/ch3s3-es.html (24.7.2017).

Uhan, J. 2007: Trendi velikih in malih pretokov rek v Slovenji. Ujma 21.

Ulaga, F. 2002: Trendi spreminjanja pretokov slovenskih rek. Dela 18.

Ulaga, F., Kobold, M., Frantar, P. 2008a: Trends of river discharges in Slovenia. IOP Conference Series: Earth and Environmental Science 4-1. DOI: https://doi.org/10.1088/1755-1307/4/1/012030

Ulaga, F., Kobold, M., Frantar, P. 2008b: Analiza časovnih sprememb vodnih količin slovenskih rek. 19. Mišičev vodarski dan. Maribor. 
Vertačnik, G., Dolinar, M., Bertalanič, R., Klančar, M., Dvoršek, D., Nadbath, M. 2015: Ensemble homogenization of Slovenian monthly air temperature series. International Journal Climatology 35-13. DOI: https://doi.org/10.1002/joc.4265

Zampieri, M., Scoccimarro, E., Gualdi, S., Navarra, A. 2015: Observed shift towards earlier spring discharge in the main Alpine rivers. Science of the Total Environment 503-504. DOI: https://doi.org/ 10.1016/j.scitotenv.2014.06.036

Žiberna, I. 2011: Podnebne spremembe v Sloveniji. Podravina 10-20.

\section{Summary: River discharge trends in Slovenian Alps between 1961 and 2010} (translated by DEKS d. o. o.)

The main findings on changes in selected hydrological and climate variables between 1961 and 2010 can be summarized as follows:

- The 1961-2010 absolute minimum annual discharge trends are falling distinctly on ten out of twelve Alpine rivers. The trend difference is small only on the Sava Bohinjka and Soča rivers, whereas on all other rivers it exceeds at least $15 \%$. The absolute minimum discharges decreased by 0.09 to $1.85 \mathrm{~m}^{3} / \mathrm{s}$, but in the relative sense the majority of watercourses experienced a decrease of 15 to $39 \%$.

- The 1961-2010 average mean annual discharge trends are falling on all twelve Alpine rivers. Discharges decreased by 0.39 to $4.33 \mathrm{~m}^{3} / \mathrm{s}$, but in the relative sense the majority of watercourses experienced a decrease of 15 to $25 \%$; a decrease of less than $10 \%$ was only recorded for the Tolminka and Savinja rivers.

- The 1961-2010 absolute maximum annual discharge trends are falling on eight Alpine rivers and are increasing on four. Among the rivers with a negative trend, the discharge decreased the most on the Mostnica $(-57 \%)$ and Kamniška Bistrica $(-49 \%)$, and, among the rivers with a positive trend, the discharge increased the most on the Tržiška Bistrica (31\%) and Soča (21\%).

- The 1961-2010 average annual air temperature increased from 0.030 to $0.038^{\circ} \mathrm{C}$ per year at seven temperature stations, which means that temperatures there increased by 1.48 to $1.84^{\circ} \mathrm{C}$ in fifty years. A slightly smaller increase in temperature was only established at the Mount Krvavec temperature station, where the temperature increased by $0.93^{\circ} \mathrm{C}$.

- The 1961-2010 annual precipitation decreased at nine out of twelve Alpine precipitation stations. At the five stations that showed the largest decrease, the average annual precipitation decreased by 4 to $9 \mathrm{~mm}$ per year, which means that over the last half century precipitation has decreased by 185 to $465 \mathrm{~mm}$, or 10 to $23 \%$, at these stations. The Mount Kredarica and Soča stations show an increasing annual precipitation trend: at both of them, precipitation has increased by approximately $10 \%$ over the past fifty years.

- The 1961-2010 annual number of days with precipitation over $0.1 \mathrm{~mm}$ increased at six precipitation stations and decreased at six. At the majority of stations, negative or positive trend deviations are smaller and do not reach $10 \%$. Stronger decreases were only observed at the Podpeca $(-13.3 \%)$ and Šmartno pri Slovenj Gradcu (-11.6\%) stations, and the greatest increases were established at the Kamniška Bistrica (30.7\%), Koprivna (23.4\%), and Bohinjska Bistrica (16.7\%) stations.

- The 1961-2010 number of days with snow cover decreased by 23 to 50 days, or 16 to $49 \%$, at eleven Alpine precipitation stations out of twelve. The only exception was the high-mountain station on Mount Kredarica, where the number of days with snow cover increased by 6 days, or $2.2 \%$.

- A comparison of the discharge regime based on the 1981-2010 data series and the discharge regime based on the 1961-1990 data series shows that the spring (primary) and fall (secondary) discharge maximums are becoming increasingly similar, that the winter (primary) and summer (secondary) discharge minimums are becoming increasingly more distinct, and that the December rise in discharge is especially strong, indicating a »late« winter. 
- More than $70 \%$ of the Slovenian Alpine landscape is covered by forest, which through interception and transpiration significantly reduces the volume of water that reaches the groundwater and surface watercourses. 